\title{
Using current protection status to assess conservation priorities
}

\author{
Kelly M. Cassidy ${ }^{\mathrm{a}, *}$, Christian E. Grue a, Michael R. Smith ${ }^{\mathrm{a}, 1}$, Richard E. Johnson ${ }^{\mathrm{b}}$, \\ Karen M. Dvornich a, Kelly R. McAllister ${ }^{\mathrm{c}}$, Philip W. Mattocks Jr. ${ }^{\mathrm{d}}$, \\ Jane E. Cassady ${ }^{\mathrm{a}, 2}$, Keith B. Aubry ${ }^{\mathrm{e}}$ \\ ${ }^{a}$ Washington Cooperative Fish and Wildlife Research Unit, Mail Stop 355020, University of Washington, Seattle, WA 98195-5020, USA \\ ${ }^{\mathrm{b}}$ Department of Zoology, Box 4236, Washington State University, Pullman, WA 99164, USA \\ ${ }^{\mathrm{c}} 600$ Capitol Way N., Washington State Department of Fish and Wildlife, Olympia, WA 98501, USA \\ ${ }^{\mathrm{d} D e p a r t m e n t ~ o f ~ B i o l o g y, ~ C e n t r a l ~ W a s h i n g t o n ~ U n i v e r s i t y, ~ E l l e n s b u r g, ~ W A ~ 98926, ~ U S A ~}$ \\ ${ }^{\mathrm{e}}$ USDA Forest Service, Pacific Northwest Research Station, 3625 93rd Ave. SW, Olympia, WA 98512-9193, USA
}

Received 24 July 1999; received in revised form 28 April 2000; accepted 20 May 2000

\begin{abstract}
Several recent studies base assessment of conservation priorities primarily on the current protection status of vertebrate species and vegetation communities. Our objective was to compare prioritization using current protection status alone with prioritization using more traditional methods. We mapped land cover of Washington State at a 100 ha minimum mapping unit using 1991 Landsat satellite thematic mapper imagery, and modeled the distributions of all breeding terrestrial vertebrates in the State using the land cover map. We determined the level of protection for each vertebrate species based on its current modeled distribution and for vegetation communities based on their current mapped distribution. We also compiled subjective lists of vertebrate species most at risk from human activities and vertebrate species most well-adapted to human activities, and we used information about potential vegetation and historic conditions to determine past anthropogenic conversion of vegetation communities. We concluded that, while knowledge of current protection status is critical for assessing conservation priorities, use of such information without ecological context (potential vegetation and historic conditions for vegetation and habitat requirements, population trends, and historic distribution for vertebrates) can give results that would direct scarce conservation resources to species and communities unlikely to need protection in the foreseeable future. (C) 2000 Elsevier Science Ltd. All rights reserved.
\end{abstract}

\section{Introduction}

Traditionally, species and communities perceived as having undergone the greatest decline due to anthropogenic activities or that appeared to be most vulnerable to future declines have been considered high conservation priorities. Scott et al. (1993) suggested that this method, particularly in its most extreme application of rescuing species on the brink of extinction, expends scarce conservation resources at the expense of many more species with less public appeal. They proposed that a prioritization method based on current

\footnotetext{
* Corresponding author. Tel.: + 1-206-543-6475; fax: + 1-206-6169012.

${ }^{1}$ Present address: Maine Department of Environmental Protection, State House Station 17, Augusta, ME 04333-0017.

2 Present address: TerraLogic GIS, 344 N. Sunset Dr., Camano Island, WA 98292, USA.
}

representation on protected areas would be a more costeffective method of allocating conservation resources. Several subsequent studies (e.g. Caicco et al., 1995; Edwards et al., 1995; Kiester et al., 1996; Merrill et al., 1996; Stoms et al., 1998) have used this method to prioritize conservation needs for vertebrate species and vegetation communities.

We mapped land cover for Washington State and, using this map, modeled the distributions of all breeding terrestrial vertebrates in the State. Protection status of vegetation communities and vertebrate species was determined by overlaying land ownership with the land cover and predicted vertebrate distributions. We also mapped vegetation zones and subjectively determined the vertebrate species most at-risk of future population declines independent of their current protection status. Vegetation zones were used to assist in mapping the distributions of vegetation communities, modeling vertebrate distributions, and estimating anthropogenic change. 
Here, we (1) compare the results of assessing conservation priorities for vegetation communities based on current protection status of extant vegetation with prioritization based on historic extent and anthropogenic change, and (2) compare the results of assessing conservation priorities for vertebrates based on current protection status with prioritization based on an independent subjective evaluation of vertebrate species currently most at-risk of future declines due to anthropogenic activities. Our objective was to compare prioritization based on current protection status with prioritization based on more traditional methods.

\section{Methods}

Detailed methods of land cover classification, vertebrate modeling, selection of at-risk species, and assignment of conservation status are provided in Cassidy et al. (1997). Detailed descriptions of vegetation communities are provided in Cassidy et al. (Vol. 1). Here, we provide a brief overview of the methods and a brief description of vegetation types.

\subsection{Study area and vegetation descriptions}

Washington State covers 17 million ha. The Cascade range divides the State into a wet, west side and a drier, east side. The natural cover of most of the west side is wet conifer forest. The natural vegetation of most of the lowest elevations of the east side is grassy steppe. Eastside forests above steppe are mostly drier than west-side forests. Elevations in the State range from sea level to $4392 \mathrm{~m}$ (the top of Mt. Rainier).

Because we could not reliably distinguish vegetation communities of similar structure using TM imagery, we used vegetation zones to assist in landcover mapping (Fig. 1). Vegetation zones integrate ancillary information about elevation, precipitation and location. They are areas over which similar assemblages of natural communities tend to form; for example, natural vegetation of the Ponderosa pine zone includes open woodlands dominated by Ponderosa pine and riparian areas dominated by hardwoods. In Washington State, where steep elevation and precipitation gradients create relatively distinct boundaries between vegetation communities, vegetation zones (in some form and sometimes using different terminology) are commonly used for organizing and describing ecological information (e.g. Daubenmire and Daubenmire, 1968; Daubenmire, 1970; Franklin and Dyrness, 1973; Hall, 1973; Brockway et al., 1983; Williams and Lillybridge, 1983; Topik et al., 1986; Henderson et al., 1989; Topik 1989; Henderson et al., 1992). Our zone boundaries were adapted from Daubenmire (1970), Franklin and Dyrness (1973), Colville National Forest (1978), Harris and Chaney (1984), and personal consultation with Jan Henderson (Mt. Baker, Snoqualmie National Forest, Montlake Terrace, Washington), Rex Crawford (Washington State Natural Heritage Program, Olympia, Washington) and David

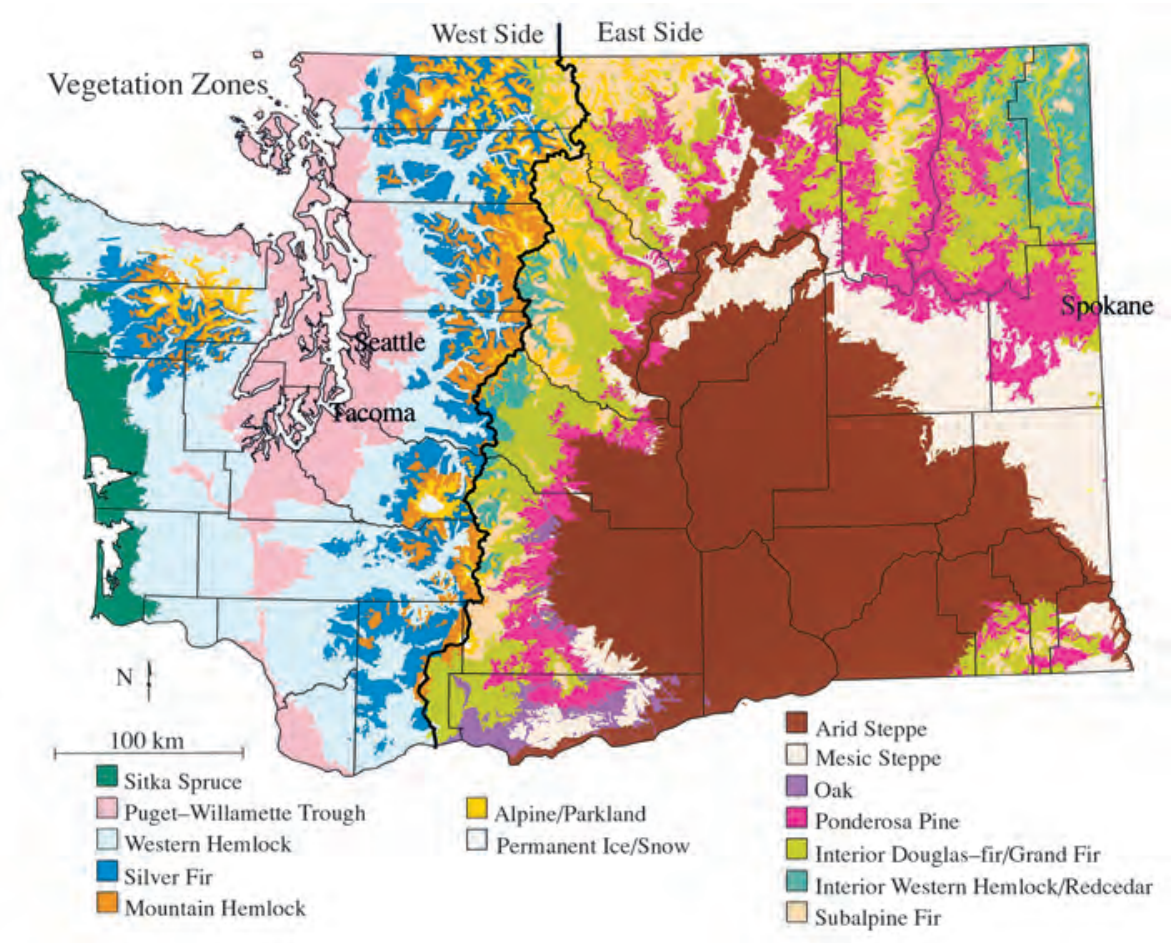

Fig. 1. Vegetation zones of Washington State. 
Pater (ManTech Environmental, Corvallis, Oregon), and were refined where possible with ground visits and satellite imagery (e.g. the approximate boundary between steppe and forest and between open and closed forest is usually apparent on TM imagery).

\subsubsection{Steppe zones}

Steppe in Washington can be divided into as many as nine zones or aggregated into two zones (as we have done here): Mesic steppe and arid steppe (Daubenmire, 1970). The mesic steppe zone forms an interrupted perimeter between woodlands and arid steppe, and is characterized by lush, meadow-like communities that form a dense ground cover and have a conspicuous amount of large perennial forbs mingled with the dominant grasses (Daubenmire, 1970). Festuca idahoensis is the dominant or co-dominant grass in most upland native mesic steppe communities. Arid steppe has more open vegetation and forbs are less conspicuous. Agropyron spicatum, and/or Artemisia tridentata are usually dominants or co-dominants of native arid steppe communities (Daubenmire, 1970). Upland communities in both steppe zones are commonly dominated by exotic annuals, notably Bromus tectorum (Mack, 1986). Woodland communities in steppe, found in ravines and on north slopes, are usually dominated by Pinus ponderosa (Daubenmire, 1970).

\subsubsection{East-side forest zones}

The Ponderosa pine (Pinus ponderosa) zone is the open-forest zone transitional between steppe at lower elevations and closed forest at higher elevations (Fig. 1). The Oak (Quercus garryana) zone occurs in a small area in south-central Washington between the steppe zones and the Ponderosa pine zone or replacing the Ponderosa pine zone. The interior Douglas-fir/Grand fir (Pseudotsuga menziesii/Abies grandis) zone is usually the closed forest zone above the Ponderosa pine zone. The interior western hemlock/western redcedar (Tsuga heterophylla/Thuja plicata) zone occurs above the interior Douglas-fir/Grand fir zone in areas where there is sufficient precipitation. The subalpine fir (Abies lasiocarpa) zone is generally the subalpine zone of the east side.

2.1.2.1. Oak (Quercus garryana) zone. The oak zone is characterized by woodlands and savannas dominated by Quercus garryana or mixed stands of Quercus garryana, Pinus ponderosa and Pseudotsuga menziesii, interspersed with dry meadows with a composition similar to that of mesic steppe (Franklin and Dyrness, 1973; Taylor and Boss, 1975); forests on north slopes may lack Quercus garryana and be dominated by Pinus ponderosa and Pseudotsuga menziesii. Wooded riparian areas are dominated by Quercus garryana, Populus trichocarpa, and Salix spp. (Franklin and Dyrness, 1973).
2.1.2.2. Ponderosa pine (Pinus ponderosa) zone. The Ponderosa pine zone is characterized by open woodlands dominated by Pinus ponderosa and interspersed with dry meadows with a composition similar to that of adjacent steppe (Daubenmire and Daubenmire, 1968; Franklin and Dyrness, 1973; Hall, 1973; Williams and Lillybridge, 1983; Williams et al., 1990; Johnson and Clausnitzer, 1992). Wetlands are typically dominated by Populus tremuloides, Populus trichocarpa, Pinus contorta and a variety of shrubs and herbs (Daubenmire and Daubenmire, 1968; Franklin and Dyrness, 1973).

\subsubsection{Interior Douglas-fir/Grand fir (Pseudotsuga} menziesii/Abies grandis) zone. The interior Douglas-fir/ Grand fir zone is characterized by diverse, closed conifer forest dominated by Pseudotsuga menziesii, Abies grandis, Pinus ponderosa, Larix occidentalis, and/or Pinus contorta (Daubenmire and Daubenmire, 1968; Hall, 1973; Williams and Lillybridge, 1983; Agee and Kertis, 1986; Topik et al., 1986; Annable and Peterson, 1988; Topik 1989; Williams et al. 1990; Johnson and Clausnitzer, 1992). Hardwood and mixed forests are rare, usually dominated by Populus tremuloides and often associated with wetlands. Wooded wetlands are usually dominated by Populus tremuloides, Populus trichocarpa, Picea engelmannii and/or Pinus contorta (Annable and Peterson, 1988; Williams et al. 1990).

2.1.2.4. Interior western redcedar/western hemlock (Thuja plicata/Tsuga heterophylla) zone. The interior western redcedar/western hemlock zone has conifer forests usually dominated by Thuja plicata and Tsuga heterophylla, with Abies grandis, Pseudotsuga menziesii, Larix occidentalis, Pinus monticola, Pinus contorta and Picea engelmannii in younger forests (Daubenmire and Daubenmire, 1968; Franklin and Dyrness, 1973; Williams et al., 1990). Hardwood forests are rare and usually limited to Alnus sinuata stands (Daubenmire and Daubenmire, 1968).

2.1.2.5. Subalpine fir (Abies lasiocarpa) zone. Conifer forest in the subalpine fir zone is dominated by Abies lasiocarpa, Picea engelmannii, Pinus contorta and Larix occidentalis (Daubenmire and Daubenmire, 1968; Franklin and Dyrness, 1973; Agee and Kertis, 1986; Annable and Peterson, 1988; Henderson et al., 1989; Williams et al., 1990; Henderson et al., 1992; Johnson and Clausnitzer, 1992). The rare hardwood forests are usually dominated by Alnus sinuata or other small trees/ large shrubs (Johnson and Clausnitzer, 1992). Meadows include a variety of subalpine herbs and shrubs and sometimes, especially on the dry southern aspect, resemble mesic steppe communities (Daubenmire and Daubenmire, 1968; Franklin and Dyrness, 1973; Annable and Peterson, 1988; Johnson and Clausnitzer, 1992) Wetlands, which include small lakes, subalpine 
bogs, and riparian areas, support Picea engelmannii, Pinus contorta, Populus tremuloides and Populus trichocarpa stands and a variety of shrubs and herbs (Daubenmire and Daubenmire, 1968; Williams et al., 1983; Annable and Peterson, 1988; Williams et al., 1990).

\subsubsection{West-side forest zones}

Both the Puget-Willamette trough and Sitka spruce (Picea sitchensis) zones are generally between sea level and $150 \mathrm{~m}$, but the former zone is inland and the latter fronts the Pacific ocean. The western hemlock (Tsuga heterophylla), silver fir (Abies amabilis), and mountain hemlock (Tsuga mertensiana) zones are, respectively, at increasingly higher elevations (Fig. 1).

2.1.3.1. Puget-Willamette trough zone. The Puget-Willamette trough zone has the driest climate of the west side. Conifer forests of all ages are usually dominated by Pseudotsuga menziesii, with Tsuga heterophylla becoming more important in mid- and late-seral forests (Evans and Fibich, 1987; Franklin and Dyrness, 1973). Most hardwood and mixed forest are early-seral forests dominated by Alnus rubra, Acer macrophyllum and Pseudotsuga menziesii (Call, 1974). Dominant trees of wetlands are usually Alnus rubra, Populus trichocarpa, Salix spp. (Call, 1974; Evans and Fibich, 1987). West-side prairies and woodlands are a unique feature of this zone characterized by mesic steppe-like prairies and savannas dominated by Quercus garryana and Pseudotsuga menziesii (Lang, 1961; Franklin and Dyrness, 1973). Common dominant trees in wetlands are Populus trichocarpa, Fraxinus latifolia, Acer macrophyllum and Alnus rubra (Franklin and Dyrness, 1973). Poorly drained swamp and bog communities are abundant (Franklin and Dyrness, 1973).

2.1.3.2. Sitka spruce (Picea sitchensis) zone. The Sitka spruce zone is characterized by late-seral forests dominated by Picea sitchensis and Tsuga heterophylla. Mosses and lichens are abundant. These forest are the archetypal Pacific Northwest "old growth" rain forest (Franklin and Dyrness 1973; Arno and Hammerly 1977; Henderson et al. 1989). Younger forests are dominated by Alnus rubra, Picea sitchensis, and/or Tsuga heterophylla (Franklin and Dyrness, 1973; Henderson et al., 1989). Wetlands in our classification include beaches and estuaries, as well as riparian areas and lakes. Dominant riparian trees are Alnus rubra, Salix spp., Acer macrophyllum, Picea sitchensis (Franklin and Dyrness, 1973; Fonda 1974). Forested swamps are dominated by Thuja plicata and Alnus rubra (Franklin and Dyrness 1973).

2.1.3.3. Western hemlock (Tsuga heterophylla) zone. Early-seral conifer forests in this zone are dominated by Pseudotsuga menziesii and Tsuga heterophylla; as the forest ages, Pseudotsuga menziesii slowly declines and Tsuga heterophylla and Thuja plicata increase, so that late-seral forests are usually dominated by Tsuga heterophylla, Pseudotsuga menziesii and Thuja plicata (Fonda and Bliss, 1969; Franklin and Dyrness, 1973; del Moral and Fleming, 1979; Agee and Kertis, 1986; Topik et al., 1986; Franklin et al., 1988; Henderson et al., 1989, 1992). Late-seral forests in this zone and the neighboring Sitka spruce zone are often referred to as Pacific Northwest "old-growth" rain forests. Hardwood and mixed forests are most common on disturbed sites and are typically dominated by Alnus rubra (Franklin and Dyrness, 1973; Franklin et al., 1988; Henderson et al., 1989, 1992). Riparian areas are usually lined with Populus trichocarpa, Fraxinus latifolia, Acer macrophyllum and Alnus rubra (Franklin and Dyrness, 1973; Agee and Kertis, 1986). Thuja plicata communities are frequently encountered on wet sites (Franklin and Dyrness, 1973; Topik et al, 1986).

2.1.3.4. Silver fir (Abies amabilis) zone. Late-seral conifer forests in this zone are usually dominated by Abies amabilis and Tsuga heterophylla (Franklin, 1966; Fonda and Bliss, 1969; Franklin and Dyrness, 1973; del Moral and Long, 1977; Brockway et al., 1983; Agee and Kertis, 1986; Franklin et al., 1988; Vanbianchi and Wagstaff, 1988; Henderson et al., 1989, 1992). Early-seral forests are dominated by Tsuga heterophylla, Abies amabilis, and, on lower-elevation or drier sites, Pseudotsuga menziesii or Abies procera (Franklin, 1966; Franklin and Dyrness, 1973; Brockway et al., 1983; Henderson et al., 1989). The rare hardwood or mixed forests are associated with riparian areas, lower elevations, or avalanche chutes; they are dominated by Acer macrophyllum, Populus trichocarpa and/or Alnus sinuata (Franklin and Dyrness, 1973; Vanbianchi and Wagstaff, 1988). There are many types of mountain meadows in this near-subalpine zone (Franklin and Dyrness, 1973). In swamps, trees are usually limited to hummocks and include Thuja plicata, Populus trichocarpa, Picea engelmannii, Chamaecyparis nootkatensis, Pinus monticola and Alnus rubra (Franklin, 1966).

2.1.3.5. Mountain hemlock (Tsuga mertensiana) zone. The mountain hemlock zone has late-seral forests dominated by Tsuga mertensiana and Abies amabilis and sometimes Chamaecyparis nootkatensis (Fonda and Bliss, 1969; Franklin and Dyrness, 1973; del Moral and Long, 1977; Brockway et al., 1983; Agee and Kertis, 1986; Henderson et al., 1989, 1992). Most early-seral forests are dominated by the same tree species (Franklin and Dyrness, 1973; Henderson et al., 1989, 1992). Marshes and boggy meadows are common in this zone (Franklin and Dyrness 1973). Hardwood forests/tall shrubs are usually Alnus sinuata in avalanche chutes.

\subsubsection{Highest-elevation zones}

The alpine/parkland zone is composed of a large variety of subalpine and alpine meadows, shrub fields, 
parkland, krummholz, small stands of subalpine tolerant conifers, and related communities (Daubenmire and Daubenmire 1968; Kuramoto and Bliss, 1970; Franklin and Dyrness, 1973; Arno and Hammerly, 1977; Douglas and Bliss, 1977; del Moral, 1979; Williams and Lillybridge 1983; Agee and Kertis, 1986; Annable and Peterson, 1988; Franklin et al., 1988; Henderson et al., 1989, 1992; Williams et al., 1990), most described on a scale below our level of resolution. In drier climates, especially on the east side, hardwood stands of Populus tremuloides may form (Williams and Lillybridge, 1983; Williams et al., 1990). The permanent ice/snow zone is largely covered by bare rock and permanent ice and snow, with some isolated high-elevation alpine vegetation in warm microsites.

\subsection{Land cover mapping}

To map actual land cover, we spectrally clustered 1991 Landsat thematic mapper (TM) image data into approximately 200 classes per scene, and classes were grouped by similar spectral value. We manually delineated areas of similar land cover type using the clustered TM imagery as a backdrop and a nominal minimum mapping unit of 100 ha (Fig. 2). Some landscape features smaller than 100 ha were mapped if they were important to vertebrate distributions (e.g. islands and wetlands). We based label information on visual interpretation of the TM data and available ground data. Label information included vegetation zone; actual primary, secondary and tertiary land cover; and

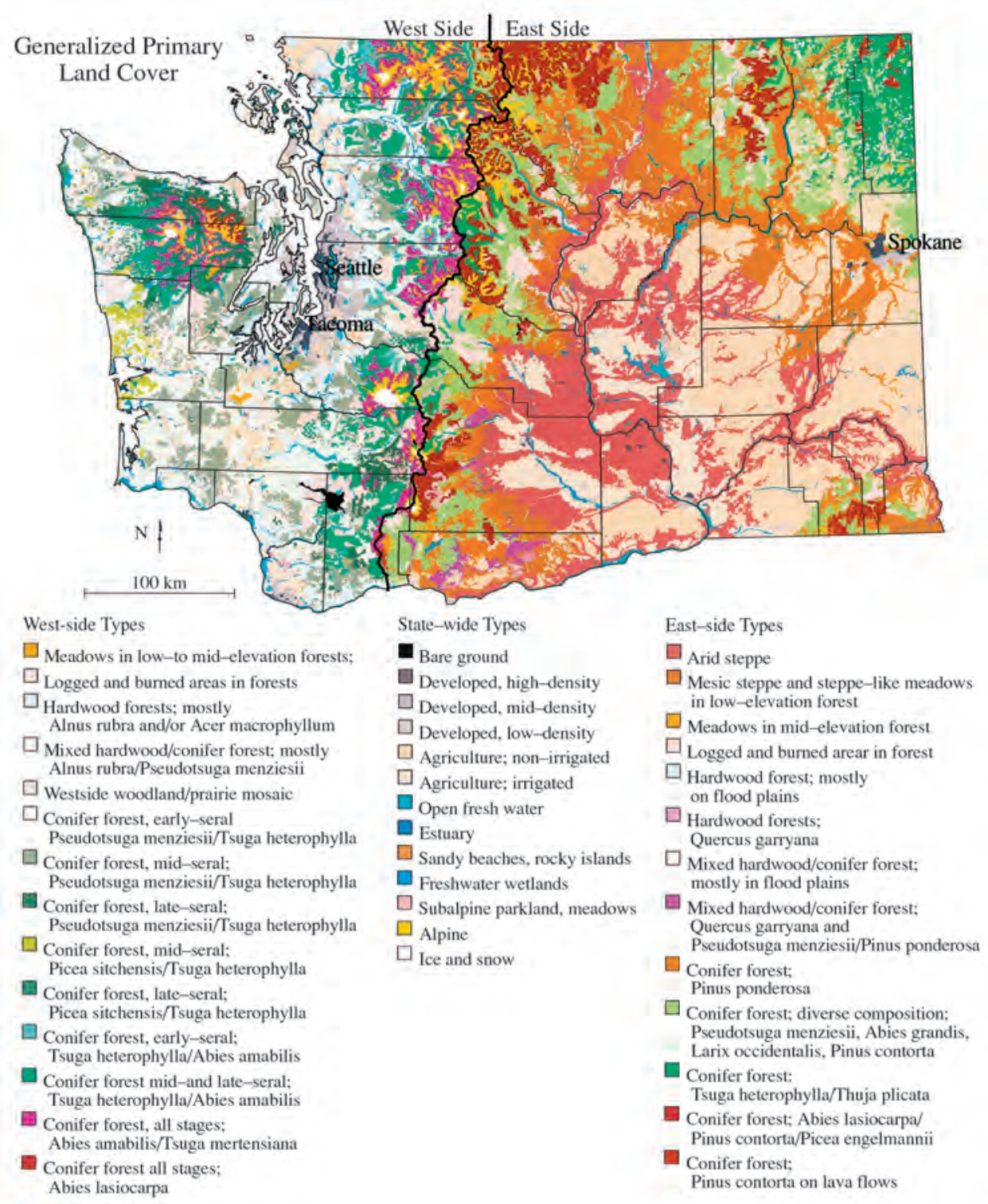

Fig. 2. Land cover of Washington State. 
primary, secondary and tertiary cover occupation class, which indicated the approximate percentage area of a polygon occupied by each cover. Primary cover was the cover occupying the greatest percentage of the polygon; secondary and tertiary covers, if needed, were the covers occupying the second and third greatest percentage of the polygon, respectively.

We assigned land cover labels based on spectral signature, plus pattern, location, and ancillary spatial data. For example, logged areas in forest were usually distinguished from apparently natural meadows by the typically straight edges of the former. Large burns were usually obvious by their extent and pattern. Road patterns helped to distinguish developments, logged areas and small farms.

\subsubsection{Limitations of TM imagery}

Most wetlands are too small or too narrow to be detected with TM data. Hydrology helped in identifying riparian corridors and other wetlands. Wetlands were easiest to distinguish from surrounding upland in steppe zones. We did not use National Wetlands Inventory (NWI) data because of the large size of the files, the variable scale at which wetlands were mapped by NWI in Washington, and the questionable quality of the data.

We could not reliably distinguish upland steppe communities dominated by native vegetation from those dominated by exotics, so our "non-forested" (steppe) class combines native and exotic-dominated communities. In west-side forest zones, we identified forest seral stage primarily by the relative evenness of the canopy. (Older forest has a less even and more shadowed canopy.) In east-side forest zones, we could not reliably distinguish forest seral stages because of the uneven surface of the canopy at all seral stages. In most forest zones, we could distinguish logged and burned areas from apparently natural meadows by patterns. In the driest east-side forest zones the regular interspersion of meadows and woodlands usually obliterated the characteristic patterns of logging and burning.

\subsection{Vertebrate distribution modeling}

We assembled a database of terrestrial vertebrate locations based primarily on museum records for amphibians, reptiles and mammals, and on recent breeding bird atlas records for birds. We developed vertebrate models by using known locations to delineate range limits, and using known locations, literature review, and expert consultation to develop habitat associations. We created predicted distributions by selecting appropriate habitats in the land cover map within each species' range limits. Only animals known to breed in Washington State were included and only their breeding distributions were modeled (i.e. wintering distributions of birds, even if they breed in Washington, were not modeled). For birds, for which there is generally good recent observational data, species were included only if there was evidence that they had probably bred in the State at least three times between 1987 and 1996. Questionable mammals, reptiles and amphibians were included if Washington State experts believed the species were currently extant and possibly breeding in the State.

Vertebrate models included indicators of habitat quality for each species based on ecoregion, vegetation zone and actual land cover. We designated vegetation zones within an ecoregion as "core" or "peripheral", where core zones were those in which the species was most common and peripheral zones were those in which the species occurred, but was much rarer or possibly not self-sustaining. We designated habitat suitability of land cover within a zone as "good", "adequate", or "contingently suitable". Good habitats were those in which the species was known to occur and breed successfully. Adequate habitats were those in which the species occurred, but was rarer or possibly not self-sustaining. Contingently suitable habitats were those that were potentially good if they contained a feature that was below the mapping resolution of the project but unlikely to occur in all habitats of similar designation (e.g. a talus slope or a pond below our mapping resolution but sufficiently large that the feature was unlikely to be in all macro-habitats). "Most suitable habitats" were those for which the primary cover of a polygon was good or contingently suitable habitat in a core zone for the species. All analyses presented here are based on the most suitable modeled habitat for each species, instead of every modeled habitat in which the species was predicted to occur. Six species modeled as occurring only peripherally as breeding species in Washington were excluded from the analysis: Preble's shrew (Sorex preblei), lesser scaup (Aythya affinis), merlin (Falco columbarius), upland sandpiper (Bartramia longicauda), green-tailed towhee (Pipilo chlorurus) and blackthroated sparrow (Amphispiza bilineata). A sample distribution map generated from a vertebrate model is shown in Fig. 3. Predicted distributions of individual species are available in Cassidy et al. (1997, Vols. 2-4) or online at http://www.wa.gov/wdfw/wlm/gap/dataprod.htm.

We defined "at risk" species as those species at risk of continued or future population declines in Washington State due to human activities. These species were subjectively determined by the authors based on species habitat requirements, known threats, and information about current population trends. They were primarily species poorly adapted to development, agriculture and logging, or that are declining or have suffered range contractions for reasons other than direct habitat loss [e.g. over-trapping or susceptibility to non-native species or brown-headed cowbird (Molothrus ater) parasitism]. We also included species about which little was 


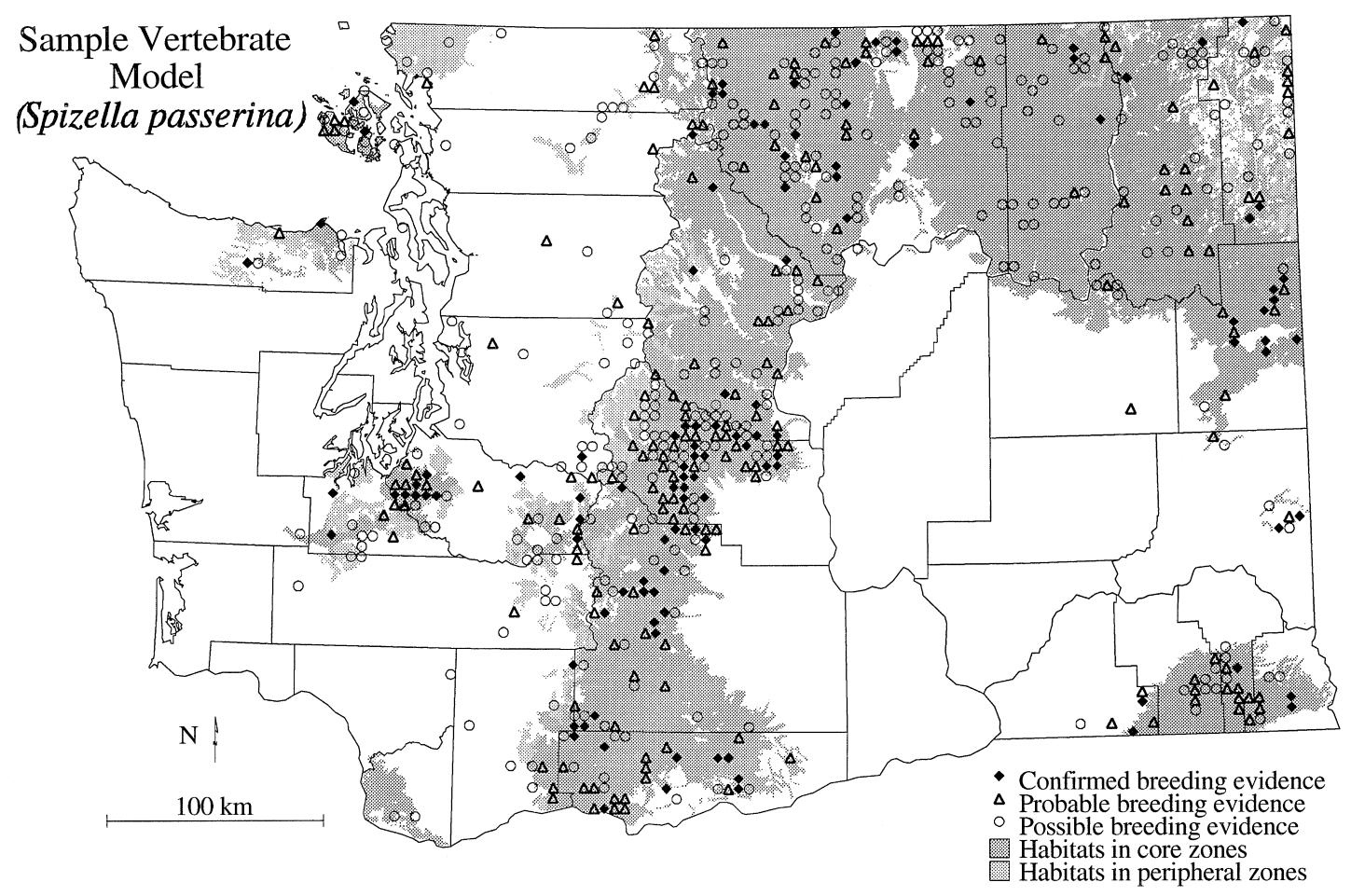

Fig. 3. Sample vertebrate model.

known, especially if combined with a low population or limited distribution. We did not limit our list of at-risk species to species listed by the State or federal government, because most listed species are very near extinction or extirpation, and the purpose of our analysis was to help protect species before they approach extinction. A list of the at-risk species is included in Appendix A. A brief discussion of the species and the reasons each was selected is provided in Cassidy et al. (1997, Vol. 5). We also subjectively compiled a list of species well-adapted to human activities that have likely benefited from logging, agriculture, or development in Washington. "Neutral" species (which, of course, are never truly neutral) were all species not included in the at-risk or well-adapted groups. There were 80 at-risk species, 54 well-adapted species, and 239 "neutral" species (373 total). Exotic species were excluded from the analyses.

\subsection{Land ownership and conservation status}

We obtained a digital map of public land ownership in Washington State from the Washington State Department of Natural Resources in 1991. We made minor corrections where errors were found or ownership was known to have changed or where further separation of some ownership types was desired.

We converted the land ownership map to a Conservation Status map by assigning four Status categories (Fig. 4). Categories were based on Scott et al. (1993), with some modifications. Status 1 lands are those maintained primarily in a natural state (e.g. National Parks and Wilderness Areas); status 2 lands are those maintained mostly in a natural state but with some extractive uses (e.g. National Wildlife Refuges, State Wildlife Areas, National Recreation Areas); status 3 lands have some protection from development but are subject to either broad, low-intensity or locally intense extractive uses (e.g. National Forest multiple use lands, Washington State Department of Natural Resource Trust lands, most Bureau of Land Management lands); and status 4 lands are lands with little or no legislated protection (e.g. private lands, Tribal lands, most Department of Defense and Department of Energy lands). In practice, we usually treated status 1 and 2 lands similarly with respect to conservation status.

\subsection{Accuracy assessment}

Resource limitations prevented statistically-valid accuracy assessments of the land cover and vertebrate models. The greatest potential sources of error for the land cover map are listed in Cassidy et al. (1997, Vol. 1). Most of the problems we had with land-cover mapping involved gradations between categories, e.g. recently logged areas are clearly distinguishable from late-seral forest, but a disturbed area regrown to tall shrubs is not easily distinguished from a disturbed area regrown to early-seral forest. In rugged terrain, deep shadows on north slopes complicate land-cover labeling; shadowing was most severe at higher elevations. 


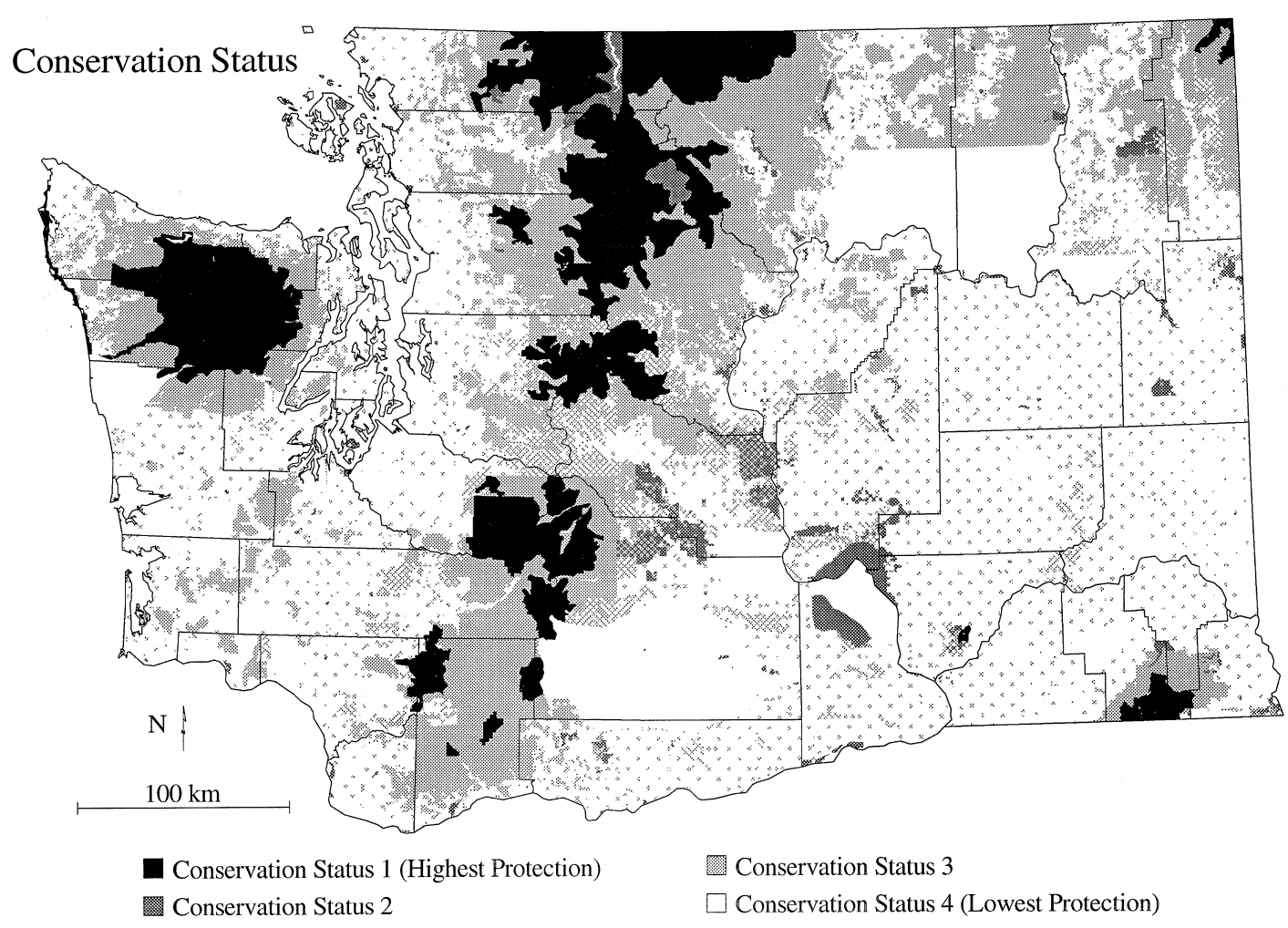

Fig. 4. Conservation status of Washington State based on land ownership and management.

As an alternative to a true accuracy assessment, we compared our land cover results to the results of land cover studies at similar scales in Washington State. We limited our comparison to fairly distinct cover types because of the problems with fuzzy cover type transitions and the difficulty in cross-walking classification systems. We found two suitable studies, one that involved an estimate of "old-growth" forest in the western Cascades, and one that estimated current steppe coverage in eastern Washington.

Spies and Franklin (1988) estimated that $17 \%$ of "old-growth," commercially viable Pseudotsuga menziesii/Tsuga heterophylla forest lands existing in pre-European times remained in the western Cascades of Washington and Oregon at the time of their study (the late 1980s). Their estimates were based on a combination of inventories of commercial forest lands from the 1970s, and estimated rates of logging since the inventories, plus the assumption that $60 \%$ of commercial forest land was originally covered by old-growth forests. If we assume that "commercial forest lands" correspond to western Washington forest zones below the silver fir zone (Puget-Willamette trough, Sitka spruce, and western hemlock zones) and that "old-growth" corresponds to our "late-seral" forest category in those zones, then our results indicate that $13 \%$ of the original old-growth remains in those three zones.

Dobler et al. (1996), primarily using TM-mapping from 1986 imagery, estimated that about $59 \%$ of steppe in Washington had been converted to agriculture or development. If we assume that all the area in the steppe zones currently in development and agriculture was once shrub-steppe, then our estimate is that about $55 \%$ of steppe has been converted. The results of Dobler et al. (1996) were based on the majority of steppe area in Washington, but excluded the northern, eastern and southern perimeter of the steppe zones.

In lieu of an accuracy assessment of amphibian and reptile models, we did an intermediate test of errors of omission (i.e. cases in which the species is observed but not predicted) on draft amphibian and reptile models. The test was based on a set of record locations added to the database after the draft models were constructed. For amphibians, the average percentage of test points falling outside the draft modeled distributions for the appropriate species was 4\% (26 species; range: $0-33 \%$; $n=2-383$ points per species, total $n=1,541$ ). For reptiles, the average percentage of test points falling outside the draft modeled distributions was 5\% (18 species; range: $0-71 \% ; n=1-65$ points per species, total $n=385$ ). After the comparisons, we modified the amphibian and reptile models to account for the test point locations, usually by expanding the range limits of the species. Therefore, the resulting maps were based on all the available information. For more details, see Cassidy et al. (1997, Vol. 5).

We also conducted an intermediate assessment of preliminary models for 47 breeding bird species in the 
Table 1

Generalized land cover of vegetation zones

\begin{tabular}{|c|c|c|c|c|c|c|c|c|c|c|c|}
\hline & $\begin{array}{l}\text { Bare } \\
\text { ground } \\
(\%)\end{array}$ & $\begin{array}{l}\text { Development } \\
(\%)\end{array}$ & $\begin{array}{l}\text { Agriculture } \\
(\%)\end{array}$ & $\begin{array}{l}\text { Water/ } \\
\text { wetlands } \\
(\%)\end{array}$ & $\begin{array}{l}\text { Non- } \\
\text { forested } \\
(\%)\end{array}$ & $\begin{array}{l}\text { Forest } \\
(\%)\end{array}$ & & & & & $\begin{array}{l}\text { Total } \\
\text { Area } \\
\text { (ha) }\end{array}$ \\
\hline \multicolumn{12}{|l|}{ Steppe zones } \\
\hline Blue mountains steppe & 0.00 & 0.00 & 23.16 & 2.30 & 61.44 & 13.10 & & & & & 64,900 \\
\hline Palouse & 0.00 & 0.80 & 88.07 & 1.31 & 6.73 & 3.09 & & & & & 467,500 \\
\hline Three-tip sage & 0.00 & 0.19 & 39.26 & 2.51 & 51.58 & 6.45 & & & & & $1,087,000$ \\
\hline Klickitat meadow steppe & 0.00 & 0.48 & 56.80 & 0.00 & 40.25 & 2.47 & & & & & 63,000 \\
\hline Bitterbrush & 0.00 & 0.13 & 44.69 & 0.00 & 54.70 & 0.48 & & & & & 24,500 \\
\hline Central arid steppe & 0.09 & 1.31 & 45.49 & 4.62 & 47.24 & 1.24 & & & & & $3,088,100$ \\
\hline Wheatgrass/fescue & 0.00 & 0.59 & 69.57 & 0.99 & 28.48 & 0.37 & & & & & 870,300 \\
\hline Canyon grassland & 0.05 & 1.89 & 18.49 & 6.45 & 71.24 & 1.88 & & & & & 209,100 \\
\hline Big sage/fescue & 0.00 & 0.28 & 75.12 & 0.59 & 24.01 & 0.00 & & & & & 205,700 \\
\hline \multirow[t]{2}{*}{ All steppe zones } & 0.05 & 0.93 & 51.05 & 3.31 & 42.37 & 2.31 & & & & & $6,080,000$ \\
\hline & $\begin{array}{l}\text { Bare } \\
\text { ground } \\
(\%)\end{array}$ & $\begin{array}{l}\text { Development } \\
(\%)\end{array}$ & $\begin{array}{l}\text { Agriculture } \\
(\%)\end{array}$ & $\begin{array}{l}\text { Water/ } \\
\text { wetlands } \\
(\%)\end{array}$ & $\begin{array}{l}\text { Non- } \\
\text { forested } \\
(\%)\end{array}$ & $\begin{array}{l}\text { Hardwood/ } \\
\text { mixed } \\
\text { forest }(\%)\end{array}$ & $\begin{array}{l}\text { Conifer } \\
\text { forest } \\
(\%)\end{array}$ & & & & \\
\hline \multicolumn{12}{|l|}{ East-side forest zones } \\
\hline Oak & 0.04 & 0.27 & 5.88 & 3.09 & 42.59 & 38.20 & 9.93 & & & & 186,900 \\
\hline Ponderosa pine & 0.04 & 2.24 & 9.70 & 3.76 & 20.84 & 1.10 & 62.31 & & & & $1,540,100$ \\
\hline Interior Douglas-fir & 0.00 & 0.12 & 5.69 & 1.26 & 18.24 & 0.53 & 74.16 & & & & $1,394,900$ \\
\hline Grand fir & 0.00 & 0.42 & 1.93 & 1.35 & 22.55 & 1.52 & 72.22 & & & & 456,700 \\
\hline $\begin{array}{l}\text { Interior redcedar and interior } \\
\text { western hemlock }\end{array}$ & 0.00 & 0.05 & 2.00 & 0.59 & 19.78 & 0.18 & 77.39 & & & & 502,900 \\
\hline Subalpine fir & 0.01 & 0.00 & 0.00 & 0.13 & 21.40 & 0.43 & 78.04 & & & & 700,200 \\
\hline Blue Mt, high open forest ${ }^{a}$ & 0.00 & 0.00 & 0.00 & 0.00 & 36.52 & 0.00 & 63.47 & & & & 9800 \\
\hline Blue Mt, high ridges ${ }^{\mathrm{a}}$ & 0.00 & 0.00 & 0.00 & 0.00 & 87.77 & 0.00 & 12.23 & & & & 500 \\
\hline Low-elevation lava flows $\mathrm{a}^{\mathrm{a}}$ & 0.00 & 0.00 & 0.00 & 0.00 & 14.99 & 0.00 & 85.01 & & & & 5200 \\
\hline High-elevation lava flows ${ }^{\mathrm{a}}$ & 0.00 & 0.00 & 0.00 & 0.00 & 62.20 & 0.00 & 37.80 & & & & 1900 \\
\hline \multirow[t]{2}{*}{ All east-side forest zones } & 0.02 & 0.81 & 5.39 & 1.90 & 21.11 & 2.22 & 68.55 & & & & $4,799,000$ \\
\hline & $\begin{array}{l}\text { Bare } \\
\text { ground } \\
(\%)\end{array}$ & $\begin{array}{l}\text { Development } \\
(\%)\end{array}$ & $\begin{array}{l}\text { Agriculture } \\
(\%)\end{array}$ & $\begin{array}{l}\text { Water/ } \\
\text { wetlands } \\
(\%)\end{array}$ & $\begin{array}{l}\text { Non- } \\
\text { forested } \\
(\%)\end{array}$ & $\begin{array}{l}\text { Hardwood/ } \\
\text { mixed } \\
\text { forest }(\%)\end{array}$ & $\begin{array}{l}\text { Conifer } \\
\text { forest } \\
\text { (early } \\
\text { serial) } \\
(\%)\end{array}$ & $\begin{array}{l}\text { Conifer } \\
\text { forest } \\
\text { (mid } \\
\text { serial) } \\
(\%)\end{array}$ & $\begin{array}{l}\text { Conifer } \\
\text { forest } \\
\text { (late } \\
\text { serial) } \\
(\%)\end{array}$ & $\begin{array}{l}\text { Conifer } \\
\text { forest } \\
\text { (mixed/ } \\
\text { unk.) } \\
(\%)\end{array}$ & \\
\hline \multicolumn{12}{|l|}{ West-side forest zones } \\
\hline Willamette valley & 0.00 & 22.20 & 44.61 & 15.91 & 1.84 & 14.67 & 0.45 & 0.06 & 0.00 & 0.26 & 70,000 \\
\hline Cowlitz river & 0.32 & 6.83 & 34.36 & 7.40 & 13.73 & 27.33 & 6.95 & 3.04 & 0.05 & 0.00 & 91,500 \\
\hline Woodland/prairie mosaic & 0.00 & 14.34 & 24.97 & 4.68 & 15.37 & 21.69 & 4.09 & 9.12 & 2.15 & 3.59 & 156,800 \\
\hline Puget sound Douglas-fir & 0.00 & 24.75 & 19.03 & 5.16 & 5.15 & 31.29 & 5.40 & 6.93 & 1.50 & 0.80 & $1,102,400$ \\
\hline Sitka spruce & 0.02 & 2.38 & 2.80 & 8.09 & 18.57 & 25.42 & 20.55 & 14.36 & 7.54 & 0.26 & 422,600 \\
\hline Western hemlock & 0.23 & 0.58 & 2.62 & 3.75 & 16.32 & 21.37 & 25.01 & 20.25 & 9.72 & 0.15 & $2,607,600$ \\
\hline Olympic Douglas-fir & 0.00 & 0.00 & 0.00 & 0.13 & 10.50 & 4.52 & 2.25 & 20.21 & 62.40 & 0.00 & 67,500 \\
\hline Silver fir & 0.57 & 0.00 & 0.00 & 0.43 & 24.34 & 3.47 & 13.36 & 13.23 & 43.88 & 0.71 & 955,600 \\
\hline Mountain hemlock & 0.89 & 0.00 & 0.00 & 0.85 & 22.97 & 2.12 & 2.51 & 2.56 & 60.44 & 7.66 & 544,900 \\
\hline All west-side forest zones & 0.28 & 5.69 & 6.51 & 3.70 & 16.01 & 18.71 & 15.86 & 13.89 & 18.21 & 1.13 & $6,018,900$ \\
\hline Highest-elevation zones & $\begin{array}{l}\text { Bare } \\
\text { ground } \\
(\%)\end{array}$ & $\begin{array}{l}\text { Development } \\
(\%)\end{array}$ & $\begin{array}{l}\text { Agriculture } \\
(\%)\end{array}$ & $\begin{array}{l}\text { Water/ } \\
\text { wetlands } \\
(\%)\end{array}$ & $\begin{array}{l}\text { Non- } \\
\text { forested } \\
(\%)\end{array}$ & & $\begin{array}{l}\text { Conifer } \\
\text { forest } \\
(\%)\end{array}$ & & & & \\
\hline \multicolumn{12}{|l|}{ Highest-elevation zones } \\
\hline Alpine/parkland & 18.38 & 0.00 & 0.00 & 0.04 & 72.09 & & 9.49 & & & & 574,200 \\
\hline \multirow[t]{2}{*}{ Permanent ice/snow } & 98.99 & 0.00 & 0.00 & 0.00 & 1.01 & & 0.00 & & & & 44,200 \\
\hline & $\begin{array}{l}\text { Bare } \\
\text { ground } \\
(\%)\end{array}$ & $\begin{array}{l}\text { Development } \\
(\%)\end{array}$ & $\begin{array}{l}\text { Agriculture } \\
(\%)\end{array}$ & $\begin{array}{l}\text { Water/ } \\
\text { wetlands } \\
(\%)\end{array}$ & $\begin{array}{l}\text { Non- } \\
\text { forested } \\
(\%)\end{array}$ & $\begin{array}{l}\text { Hardwood/ } \\
\text { mixed } \\
\text { forest }(\%)\end{array}$ & $\begin{array}{l}\text { Conifer } \\
\text { forest } \\
(\%)\end{array}$ & & & & \\
\hline Statewide & 0.97 & 2.50 & 21.43 & 2.94 & 28.36 & 7.13 & 36.67 & & & & $17,516,300$ \\
\hline
\end{tabular}

a These four zones are minor zones that could reasonably be considered to be topoedaphic subset of major zones. If they are merged with major zones, both minor Blue Mountains zones and the high-elevation lava flow zone should be incorporated into the subalpine fir zone and the low-elevation lava flow zone should be incorporated into the interior Douglas-fir zone. Discrepancies in addition are due to rounding. 
Table 2

Conservation status of vegetation zones and of undeveloped and uncultivated vegetation communities within those zones

Vegetation zone (totals) \begin{tabular}{l}
$\begin{array}{l}\text { Status } 1 \text { and } 2 \quad \text { Status } 3 \\
\text { (highest } \\
\text { protection) }\end{array}$ \\
\hline
\end{tabular}

Community types, with common dominants in parentheses ${ }^{\mathrm{a}}$

(\%) (ha)

Mesic steppe

Wetlands

Mesic steppe (Festuca idahoensis or exotic annuals)

Woodlands in steppe (Pinus ponderosa)

\section{Arid steppe}

Wetlands

Arid steppe (Artemisia tridentata/Agropyron spicatum or exotic annuals)

Woodlands in steppe (Pinus ponderosa)

Oak

Wetlands

Meadows and clearings (mesic steppe-like)

Hardwood and mixed woodlands (Quercus garryana and Quercus garryana/conifer)

Conifer woodlands (Pseudotsuga menziesii/Pinus ponderosa)

\section{Ponderosa pine}

Wetlands

Meadows and clearings (mesic steppe-like)

Hardwood and mixed forest (Populus tremuloides/Populus trichocarpa)

Conifer forest (Pinus ponderosa)

1.07

5.49

2.04

1.98

4.36

9.29

8.61

5.58

3.38

11.07

1.28

5.75

2.89

3.89

4.96

4.14

1.17

4.43

Interior Douglas-fir/grand fir

Wetlands

Meadows (mid-elevation montane)

Logged or burned

Hardwood and mixed forest (Populus tremuloides)

Conifer forest (Pseudotsuga menziesii/Abies grandis/Pinus ponderosa/Pinus contorta/Larix occidentalis)

Interior western hemlock/western redcedar

Wetlands

Meadows (high-elevation montane)

Logged or burned

Hardwood and mixed forest (Alnus sinuata)

Conifer forest (Tsuga heterophylla/Thuja plicata)

Subalpine fir

Wetlands

Meadows (subalpine)

Logged or burned

Hardwood and mixed forest (Populus tremuloides/Alnus sinuata)

Conifer forest (Abies lasiocarpa/Pinus contorta/Picea engelmannii/ Larix occidentalis)

\section{Puget-Willamette trough}

Wetlands

West-side prairies and woodlands (Quercus garryana and Pseudotsuga menziesii woodlands with Festuca idahoensis grasslands)

Logged or burned

Hardwood and mixed forest (Alnus rubra/Acer macrophyllum/ Pseudotsuga menziesii)

Conifer forest, early seral (Pseudotsuga menziesii) ${ }^{\mathrm{b}}$

Conifer forest, mid-seral (Pseudotsuga menziesii)

Conifer forest, late-seral (Pseudotsuga menziesii/Tsuga heterophylla)

\section{Sitka spruce}

Wetlands

Meadows (low-elevation montane, including headlands along the shore

Logged

Hardwood and mixed forest (Alnus rubra/Picea sitchensis)

Conifer forest, early seral (Picea sitchensis/Tsuga heterophylla) ${ }^{\mathrm{b}}$

16.33

11.02

58.62

11.52

98.35

16.10

43.51

54.26

55.41

10.97

56.92

44.59

$\begin{array}{rrrrrr}\mathbf{1 8 , 2 0 0} & \mathbf{9 . 3 4} & \mathbf{1 5 9 , 4 0 0} & \mathbf{8 9 . 5 9} & \mathbf{1 , 5 2 9 , 1 0 0} & \mathbf{1 , 7 0 6 , 8 0 0} \\ 1900 & 6.49 & 2300 & 88.02 & 30,700 & 34,900 \\ 13,700 & 13.68 & 91,800 & 84.29 & 565,400 & 670,800 \\ 1900 & 17.06 & 16,200 & 80.96 & 76,700 & 94,700 \\ \mathbf{1 9 0 , 7 0 0} & \mathbf{8 . 1 0} & \mathbf{3 5 4 , 2 0 0} & \mathbf{8 7 . 5 5} & \mathbf{3 , 8 2 8 , 7 0 0} & \mathbf{4 , 3 7 3 , 2 0 0} \\ 15,400 & 3.86 & 6400 & 86.86 & 144,300 & 166,100 \\ 164,000 & 11.05 & 210,500 & 80.35 & 1,530,700 & 1,905,100 \\ 2500 & 15.74 & 7200 & 78.67 & 35,800 & 45,500 \\ \mathbf{6 3 0 0} & \mathbf{1 3 . 8 8} & \mathbf{2 5 , 9 0 0} & \mathbf{8 2 . 7 5} & \mathbf{1 5 4 , 7 0 0} & \mathbf{1 8 6 , 9 0 0} \\ 600 & 9.12 & 500 & 79.81 & 4600 & 5800 \\ 1000 & 12.26 & 9800 & 84.46 & 67,200 & 79,600 \\ 4100 & 16.42 & 11,700 & 77.83 & 55,600 & 71,400 \\ & & & & & \\ 500 & 16.34 & 3000 & 80.76 & 15,000 & 18,600 \\ \mathbf{5 9 , 9 0 0} & \mathbf{2 4 . 6 9} & \mathbf{3 8 0 , 3 0 0} & \mathbf{7 1 . 4 1} & \mathbf{1 , 0 9 9 , 8 0 0} & \mathbf{1 , 5 4 0 , 1 0 0} \\ 2900 & 13.35 & 7700 & 81.68 & 47,400 & 58,000 \\ 13,300 & 28.35 & 91,000 & 67.51 & 216,600 & 320,900 \\ 200 & 14.70 & 2500 & 84.14 & 14,300 & 17,000 \\ 42,500 & 28.02 & 268,900 & 67.55 & 648,300 & 959,700 \\ \mathbf{1 6 5 , 4 0 0} & \mathbf{4 4 . 8 1} & \mathbf{8 3 6 , 4 0 0} & \mathbf{4 6 . 3 3} & \mathbf{8 6 4 , 8 0 0} & \mathbf{1 , 8 6 6 , 6 0 0} \\ 2300 & 10.25 & 2400 & 80.10 & 19,000 & 23,700 \\ 5700 & 55.24 & 25,200 & 32.34 & 14,700 & 45,600 \\ 9000 & 47.78 & 151,000 & 49.37 & 156,100 & 316,200 \\ 1000 & 60.40 & 8700 & 32.38 & 4700 & 14,400 \\ 139,700 & 46.16 & 634,700 & 43.68 & 600,600 & 1,374,900\end{array}$

$\mathbf{8 2 , 1 0 0} \quad \mathbf{5 7 . 5 3}$

$\begin{array}{ll}300 & 10.31\end{array}$

$4800 \quad 33.89$

$10,500 \quad 56.91$

$\begin{array}{ll}900 & 0.20\end{array}$

$62,700 \quad 60.34$

$\mathbf{3 0 5 , 7 0 0} \quad \mathbf{4 1 . 4 2}$

$500 \quad 2.95$

$47,500 \quad 24.54$

$7200 \quad 64.39$

$1700 \quad 37.46$

$244,000 \quad 42.39$

$\mathbf{2 8 9 , 3 0 0} \mathbf{2 6 . 1 3}$

$\begin{array}{ll}300 & 78.67\end{array}$

$2800 \quad 7.49$

$52,000 \quad 31.57$

$0 \quad 1.45$

$234,800 \quad 23.55$

291,000 15.07

$\begin{array}{ll}0 & 42.79\end{array}$

$21,100 \quad 20.04$

$42,300 \quad 24.64$

$1100 \quad 5.62$

$232,000 \quad 13.02$

131,400

2400

600

28,800

0

91,700

105,900

400

17,200

16,200

200

71,200

$\mathbf{5 0 2 , 9 0 0}$

3000

8200

91,300

900

389,200

702,600

900

85,800

65,620

3000

547,200

1.17

5.21

4.03

$\mathbf{1 6 , 6 0 0} \quad 6.46$

$4300 \quad 2.18$

$2600 \quad 8.04$

0.76

0.73

0.92

0.83

12.65

$\mathbf{5 . 5 2}$

11.49

29.55

0.84

1.66

0.78

$3,900 \quad 2.66$

$\begin{array}{ll}100 & 0.79\end{array}$

$\begin{array}{ll}700 & 13.48\end{array}$

$1,800 \quad 8.96$

$\begin{array}{rr}700 & 12.48\end{array}$ $\mathbf{9 1 , 8 0 0} \quad 92.3$

\begin{tabular}{ll}
$1800 \quad 92.61$ \\
\hline
\end{tabular}

$5100 \quad 87.93$

$6600 \quad 90.18$

$25,200 \quad 91.14$

\begin{tabular}{ll}
$6200 \quad 92.00$ \\
\hline
\end{tabular}

$\begin{array}{lll}17,400 & 80.57\end{array}$

$3300 \quad 70.78$

$\mathbf{4 4 , 8 0 0} \quad \mathbf{8 3 . 8 9}$

\begin{tabular}{ll}
$900 \quad 85.85$ \\
\hline
\end{tabular}

$\begin{array}{ll}0 & 69.67\end{array}$
$1,312,200$

75,900

55,700

65,700

282,100

80,200

75,400

14,200

354,500

29,400

100

67,100

96,000

76,300
$1,420,779$

82,000

63,400

72,800

309,500

87,200

93,600

20,000

422,600

34,200

200

78,300

107,400

87,900 
Table 2 (continued)

\begin{tabular}{|c|c|c|c|c|c|c|c|}
\hline \multirow{2}{*}{$\begin{array}{l}\text { Vegetation zone (totals) } \\
\text { Community types, with common dominants in parentheses }\end{array}$} & \multicolumn{2}{|c|}{$\begin{array}{l}\text { Status } 1 \text { and } 2 \\
\text { (highest } \\
\text { protection) }\end{array}$} & \multicolumn{2}{|c|}{ Status 3} & \multicolumn{2}{|c|}{$\begin{array}{l}\text { Status } 4 \\
\text { (lowest } \\
\text { protection) }\end{array}$} & \multirow[b]{2}{*}{ Total area } \\
\hline & $(\%)$ & (ha) & $(\%)$ & (ha) & $(\%)$ & (ha) & \\
\hline onifer forest, mid-seral (Picea sitchensis/Tsuga heterophylla) & 0.58 & 400 & 12.70 & 7700 & 86.73 & 52,600 & 60,700 \\
\hline Conifer forest, late-seral (Picea sitchensis/Tsuga heterophylla) & 45.99 & 14,700 & 14.87 & 4700 & 39.14 & 12,500 & 31,900 \\
\hline Western hemlock & 5.63 & 150,600 & 33.58 & 898,300 & 60.79 & $1,626,200$ & $2,675,100$ \\
\hline Wetlands & 10.83 & 10,600 & 13.14 & 12,900 & 76.03 & 74,400 & 97,900 \\
\hline Meadows (mid-montane) & 21.65 & 2900 & 68.22 & 9300 & 10.13 & 1400 & 13,600 \\
\hline Logged & 0.77 & 3200 & 33.28 & 139,500 & 65.96 & 276,400 & 419,100 \\
\hline Hardwood and mixed forest (Alnus rubra) & 1.18 & 6600 & 23.55 & 131,900 & 75.17 & 421,000 & 560,100 \\
\hline Conifer forest, early seral (Pseudotsuga menziesii/Tsuga heterophylla) ${ }^{\mathrm{b}}$ & 0.57 & 3700 & 30.83 & 202,800 & 68.59 & 451,100 & 657,700 \\
\hline Conifer forest, mid-seral (Pseudotsuga menziesii/Tsuga heterophylla) & 1.44 & 7800 & 44.43 & 240,700 & 54.13 & 293,200 & 541,700 \\
\hline $\begin{array}{l}\text { Conifer forest, late-seral (Tsuga heterophylla/Pseudotsuga menziesii/ } \\
\text { Thuja plicata) }\end{array}$ & 37.32 & 110,300 & 53.13 & 157,000 & 9.54 & 28,200 & 295,500 \\
\hline Silver fir & 29.00 & 277,100 & 53.13 & $\mathbf{5 0 7 , 7 0 0}$ & 17.87 & 170,800 & 955,600 \\
\hline Wetlands & 54.81 & 2200 & 32.19 & 1300 & 12.99 & 500 & 4100 \\
\hline Meadows (high-montane/subalpine) & 76.38 & 19,900 & 22.36 & 5800 & 1.26 & 300 & 26,100 \\
\hline Logged & 6.71 & 13,800 & 64.29 & 132,700 & 29.00 & 59,900 & 206,400 \\
\hline $\begin{array}{l}\text { Hardwood and mixed forest (Acer macrophyllum/Populus trichocarpa/ } \\
\text { Alnus sinuata) }\end{array}$ & 3.43 & 1100 & 56.27 & 18,700 & 40.30 & 13,400 & 33,200 \\
\hline Conifer forest, early seral (Tsuga heterophylla/Abies amabilis) ${ }^{\mathrm{b}}$ & 9.48 & 12,800 & 63.91 & 86,000 & 26.61 & 35,800 & 134,500 \\
\hline Conifer forest, mid-seral (Tsuga heterophylla/Abies amabilis) & 11.52 & 14,600 & 55.35 & 70,000 & 33.13 & 41,900 & 126,400 \\
\hline Conifer forest, late-seral (Abies amabilis/Tsuga heterophylla) & 48.58 & 203,700 & 46.70 & 195,800 & 4.72 & 19,800 & 419,300 \\
\hline Mountain h & 60.29 & 328,500 & 34.57 & 188,400 & 5.15 & 28,000 & 544,900 \\
\hline Wetlands & 87.68 & 4000 & 9.11 & 400 & 3.21 & 100 & 4600 \\
\hline Meadows (subalpine) & 63.20 & 46,400 & 33.00 & 24,200 & 3.80 & 2800 & 73,400 \\
\hline Logged & 18.05 & 9300 & 59.03 & 30,500 & 22.92 & 11,800 & 51,700 \\
\hline Hardwood and mixed forest (Alnus sinuata) & 56.06 & 6500 & 27.72 & 3,200 & 16.22 & 1900 & 11,600 \\
\hline Conifer forest, early seral (Tsuga mertensiana/Abies amabilis) ${ }^{\mathrm{b}}$ & 38.50 & 21,300 & 55.80 & 30,900 & 5.70 & 3200 & 55,400 \\
\hline Conifer forest, mid-seral (Tsuga mertensiana/Abies amabilis) & 44.16 & 6100 & 53.00 & 7400 & 2.84 & 400 & 13,900 \\
\hline Conifer forest, late-seral (Tsuga mertensiana/Abies amabilis) & 69.57 & 229,000 & 27.93 & 92,000 & 2.50 & 8200 & 329,300 \\
\hline Alpine/parkland & 82.87 & 475,800 & 15.43 & 88,600 & 1.70 & $\mathbf{9 , 8 0 0}$ & 574,200 \\
\hline Permanent ice/snow & 97.59 & 43,100 & $\mathbf{0}$ & $\mathbf{0}$ & 2.41 & 1,100 & 44,200 \\
\hline Statewide & 12.23 & $2,142,200$ & 23.73 & $4,156,600$ & 64.04 & $11,217,400$ & $17,516,300$ \\
\hline
\end{tabular}

a In all areas, mountain meadows and wetland communities are usually diverse assemblages with no clear dominants.

b Includes conifer forests of unknown and mixed seral stages.

Columbia Basin. Breeding bird atlas data for quads with more than 25 observed species were considered to represent "true" distribution. These data were compared with the preliminary models to calculate errors of omission and errors of commission (i.e. cases in which the species is predicted but not observed). Errors of omission for each species averaged $2.6 \%$ and ranged from $0-10 \%$. Errors of commission were generally higher, with an average of $39.2 \%$ and a range of $2-$ $82 \%$. Errors of commission were highest for species that are uncommon or difficult to observe, so many of them are not true errors. For more details, see Smith (1994).

Neither of these assessments of vertebrate models can be considered an unbiased "accuracy" assessment. For the amphibian and reptile assessments, few, if any, of the assessment records were collected by individuals who had seen the preliminary distribution maps, but most records were collected by biologists who were aware of the approximate known distribution limits of the species; these collectors were probably more likely to obtain records near the edges of or beyond the known range. Likewise, few of the volunteers collecting bird data had seen the preliminary maps, but volunteer observations tended to occur in public areas with easy access.

\section{Results}

\subsection{Current land cover and protection status}

We grouped our 14 major vegetation zones into 4 broad categories: west-side forest zones, east-side forest zones, steppe zones and high-elevation zones. Within each zone, we determined land area that was developed, in agriculture, occurring as water or wetlands, in nonforest, or in various seral stages of forest cover (Table 
1). Conifer forest is the most common landcover type in most zones, and late-seral forest percentages increase with increasing zone elevation on the west side. We then evaluated the conservation status of the various vegetation communities (or cover types) identified in each of the zones (Table 2). Generally, natural communities have a higher percentage of their extant area protected than the zone overall, except for logged areas and earlyand mid-seral forest.

\subsection{Anthropogenic change}

Development and agriculture are the easiest anthropogenic activities to quantify at the level of the vegetation zone. The vegetation zones most affected by those two activities are the mesic steppe zone $(55.1 \%$ converted to agriculture or development), arid steppe zone $(51.5 \%)$, and Puget-Willamette trough zone $(44.3 \%)$. Vegetation communities within zones, however, are unequally displaced by development and agriculture. In the steppe zones, almost all of the area under cultivation was formerly upland steppe. Most major cities in the steppe zones were initially established along rivers (displacing riparian vegetation), but have spread into surrounding steppe as they grew. If the comparatively small area in development in steppe is ignored, then roughly $58 \%$ of upland mesic steppe and $54 \%$ of upland arid steppe has been lost to cultivation. The effects of development and agriculture on individual cover types in the Puget-Willamette trough zone is more difficult to assess, since these activities have displaced a combination of forests, west-side woodland/ prairie mosaic, meadows and wetlands.

In forested zones, logging affects not only the ratio of forested to non-forested cover, but also the ratio of lateseral to other forest stages. Assessing the influence of logging requires an estimate of historic conditions. Prior to the arrival of Europeans, $60-70 \%$ of the forests in the western hemlock and Sitka spruce zone were probably in a late-seral stage (Spies and Franklin, 1988). Currently, in the Sitka spruce zone, only $7.5 \%$, and, in the western hemlock zone, only $11.0 \%$ of the area is still covered by such forests. Thus, (assuming the lower preEuropean estimate of $60 \%$ ) the extant late-seral forest in these zones only covers 12 and $18 \%$, respectively, of the area it covered in these zones prior to the arrival of Europeans. The Puget-Willamette trough zone probably had less than $60 \%$ of its pre-European area in lateseral forest, because it is a drier zone with a higher fire frequency, but the amount of late-seral forest was certainly much higher than the current $1 \%$.

Other anthropogenic activities with effects that are difficult or impossible to assess with TM imagery include grazing, introduction of exotic plants, selective logging or thinning, fire suppression, damming of rivers, and recreational activities such as hiking. Grazing and exotic plants have had a major influence on the remaining uncultivated steppe (Harris and Chaney, 1984). Grazing has also impacted many other cover types such as mountain meadows and west-side woodland/prairie mosaic (Franklin and Dyrness, 1973). Fire suppression and selective logging have probably had the greatest effect in low-elevation east-side forest zones.

\subsection{Cover types of highest priority based on anthropogenic conversion}

Based on loss due to anthropogenic conversion (Section 3.2), the 7 cover types of highest priority in Washington (in no particular order) are upland mesic steppe; upland arid steppe; late-seral forest, wetlands, and woodland/prairie mosaic in the Puget-Willamette trough zone; and late-seral forest in the Sitka spruce and western hemlock zones. All of these types probably cover less than half of their pre-European extent, and in many cases, less than $20 \%$.

\subsection{Protection status of vertebrate species and species groups}

The average percentage representation on status 1 or 2 lands for selected vertebrate groups ranges from $2.8 \%$ for turtles to $20.8 \%$ for hoofed mammals, but variance within groups is high, as indicated by the broad confidence intervals for most groups (Table 3). Groups of species (some overlapping) with the lowest percentage representation are reptiles, geese and ducks, flycatchers, listed amphibians and reptiles, at-risk reptiles, Columbia Basin-dependents, neotropical migrants, and species well-adapted to human activities. These groups all have a large number of their members restricted to low elevation forest zones or to steppe. Groups with the highest average percentage representation on status 1 or 2 lands are hoofed mammals, finches, listed birds and rodents. The average percentage representation on status 1 or 2 lands for listed amphibians and reptiles is less than for amphibians and reptiles overall; the average percentage representation for listed mammals is similar to that of mammals overall; and the average percentage representation for listed birds is much higher than for birds overall. The average percentage representation for at-risk species is similar to that of their respective groups, except that at-risk amphibians have a higher average percentage representation than amphibians overall.

We also calculated average sizes of modeled distributions for selected groups of species (Table 3). Standard deviations for sizes were high (usually similar to the average sizes), so few generalizations can be made. Average sizes of modeled distributions for amphibians and reptiles were lower than for mammals and birds. Average sizes of modeled distributions for at-risk spe- 
Table 3

Average percentage of modeled distributions on status 1 or 2 lands and average total modeled areas for selected groups of native breeding vertebrates in Washington State

\begin{tabular}{|c|c|c|c|c|c|}
\hline Group $^{\mathrm{a}}$ & $\begin{array}{l}\text { Number } \\
\text { in group }\end{array}$ & $\begin{array}{l}\text { Average } \% \text { of } \\
\text { distribution } \\
\text { on status } 1,2 \text { land }\end{array}$ & $\begin{array}{l}95 \% \\
\text { confidence } \\
\text { interval }^{\mathrm{b}}(\%)\end{array}$ & $\begin{array}{l}\text { Average } \\
\text { modeled area }\end{array}$ & $\begin{array}{l}\text { Standard } \\
\text { deviation of } \\
\text { modeled area }\end{array}$ \\
\hline Amphibians & 24 & 10.7 & $2.3-24.0$ & $2,374,742$ & $2,519,015$ \\
\hline Salamanders & 14 & 8.7 & $1.2-22.2$ & $1,665,932$ & $1,449,312$ \\
\hline Frogs and toads & 10 & 13.3 & $3.9-27.1$ & $3,385,252$ & $3,386,298$ \\
\hline Reptiles & 21 & 6.1 & $3.2-9.9$ & $1,937,196$ & $1,910,126$ \\
\hline Turtles & 2 & 2.8 & $0.0-11.0$ & 182,158 & 229,221 \\
\hline Lizards & 7 & 7.2 & $4.6-10.2$ & $1,448,385$ & 726,673 \\
\hline Snakes & 12 & 6.0 & $3.4-9.2$ & $2,335,120$ & $2,316,251$ \\
\hline Mammals & 101 & 14.4 & $2.8-33.0$ & $4,636,137$ & $4,090,445$ \\
\hline Shrews and moles & 11 & 12.7 & $6.0-21.6$ & $4,683,552$ & $3,821,392$ \\
\hline Bats & 15 & 9.4 & $4.9-15.1$ & $7,412,052$ & $4,473,622$ \\
\hline Lagomorphs & 6 & 9.8 & $0.3-30.0$ & $2,336,825$ & $2,176,422$ \\
\hline Carnivores & 19 & 15.6 & $4.4-31.9$ & $5,667,980$ & $4,576,554$ \\
\hline Hoofed mammals & 7 & 20.8 & $5.8-41.9$ & $3,383,135$ & $4,429,782$ \\
\hline Rodents & 43 & 16.1 & $1.9-40.2$ & $3,724,544$ & $3,499,132$ \\
\hline Birds & 225 & 12.4 & $0.8-34.7$ & $3,493,658$ & $3,715,630$ \\
\hline Non-passerine & 117 & 13.8 & $0.3-42.1$ & $2,598,060$ & $3,505,562$ \\
\hline Passerine & 108 & 10.5 & $1.8-25.3$ & $4,557,225$ & $3,680,009$ \\
\hline Geese and ducks & 18 & 6.3 & $1.6-13.8$ & $1,331,803$ & $1,500,987$ \\
\hline Waders & 17 & 11.4 & $1.1-30.6$ & 901,611 & $1,542,429$ \\
\hline Predators & 29 & 10.1 & $1.5-25.0$ & $4,537,586$ & $4,035,350$ \\
\hline Woodpeckers & 11 & 13.9 & $3.7-29.3$ & $4,211,727$ & $4,042,730$ \\
\hline Flycatchers & 11 & 7.3 & $2.9-13.4$ & $5,346,209$ & $3,038,732$ \\
\hline Gleaners & 19 & 10.0 & $3.0-20.3$ & $4,024,226$ & $2,996,244$ \\
\hline Finches & 11 & 19.9 & $1.3-52.7$ & $3,948,838$ & $3,348,097$ \\
\hline Sparrows & 15 & 10.5 & $2.5-22.9$ & $4,079,928$ & $2,641,412$ \\
\hline At-risk amphibians & 12 & 13.8 & $1.9-33.8$ & $1,014,291$ & $1,263,430$ \\
\hline At-risk reptiles & 7 & 6.2 & $1.9-12.7$ & $1,312,027$ & $1,027,757$ \\
\hline At-risk mammals & 24 & 14.4 & $3.2-31.6$ & $2,217,389$ & $3,239,956$ \\
\hline At-risk birds & 37 & 11.2 & $1.8-27.1$ & $1,532,524$ & $1,844,422$ \\
\hline State or federally listed amphibians & 8 & 6.4 & $0.8-16.8$ & 807,963 & $1,389,207$ \\
\hline State or federally listed reptiles & 3 & 3.2 & $0.1-10.6$ & 428,958 & 720,088 \\
\hline State or federally listed mammals & 15 & 13.6 & $1.4-35.4$ & $1,174,194$ & $1,452,006$ \\
\hline State or federally listed birds & 24 & 19.8 & $1.9-50.0$ & $1,699,478$ & $2,268,450$ \\
\hline Columbia basin-dependent amphibians & 3 & 4.6 & $2.2-7.8$ & $1,865,041$ & $1,519,338$ \\
\hline Columbia basin-dependent reptiles & 8 & 8.2 & $6.0-10.7$ & $2,376,962$ & 936,442 \\
\hline Columbia basin-dependent mammals & 20 & 5.6 & $2.2-10.3$ & $2,142,153$ & $1,897,209$ \\
\hline Columbia basin-dependent birds & 41 & 7.4 & $3.8-12.1$ & $2,038,360$ & $2,388,767$ \\
\hline Neotropical migrants (birds) ${ }^{\mathrm{b}}$ & 59 & 8.5 & $1.8-19.5$ & $4,162,122$ & $3,754,142$ \\
\hline Species well-adapted to human activity & 54 & 4.5 & $1.5-8.9$ & $5,050,067$ & $4,555,431$ \\
\hline
\end{tabular}

a Confidence limits are not symmetric about the mean because percentage data were arcsine transformed before calculating statistics (Zar, 1984).

b Based on Gauthreaux (1992).

cies were smaller than the averages for their respective groups, and average sizes of modeled distributions for listed species were smaller than averages for at-risk species, except for birds.

A histogram of percentage representation on status 1 or 2 lands for at-risk species compared to similar histograms for species well-adapted to human activities and neutral species indicates that well-adapted species are more skewed toward lower percentage representation on status 1 or 2 lands than at-risk species or neutral species (Fig. 5). The lowest percentage representation class (less than $4 \%$ of modeled distribution on status 1 or 2 lands) contains $56 \%$ (30 of 54) of species welladapted to human activities, $17 \%$ (40 of 238) of neutral species, and 19\% (15 of 80) of at-risk species. None of the species well adapted to human activities have more than $28 \%$ of their modeled distributions represented on status 1 or 2 lands, while $16 \%$ of at-risk species and $15 \%$ of neutral species have more than $28 \%$ representation.

A histogram of the absolute area of modeled distributions on status 1 or 2 lands for at-risk species compared to similar histograms for neutral species and species well-adapted to human activities (Fig. 6) indicates that at-risk species are more likely to have a smaller absolute representation on status 1 or 2 lands than either neutral species or well-adapted species; the smallest size category (less than 50,000 ha representa- 


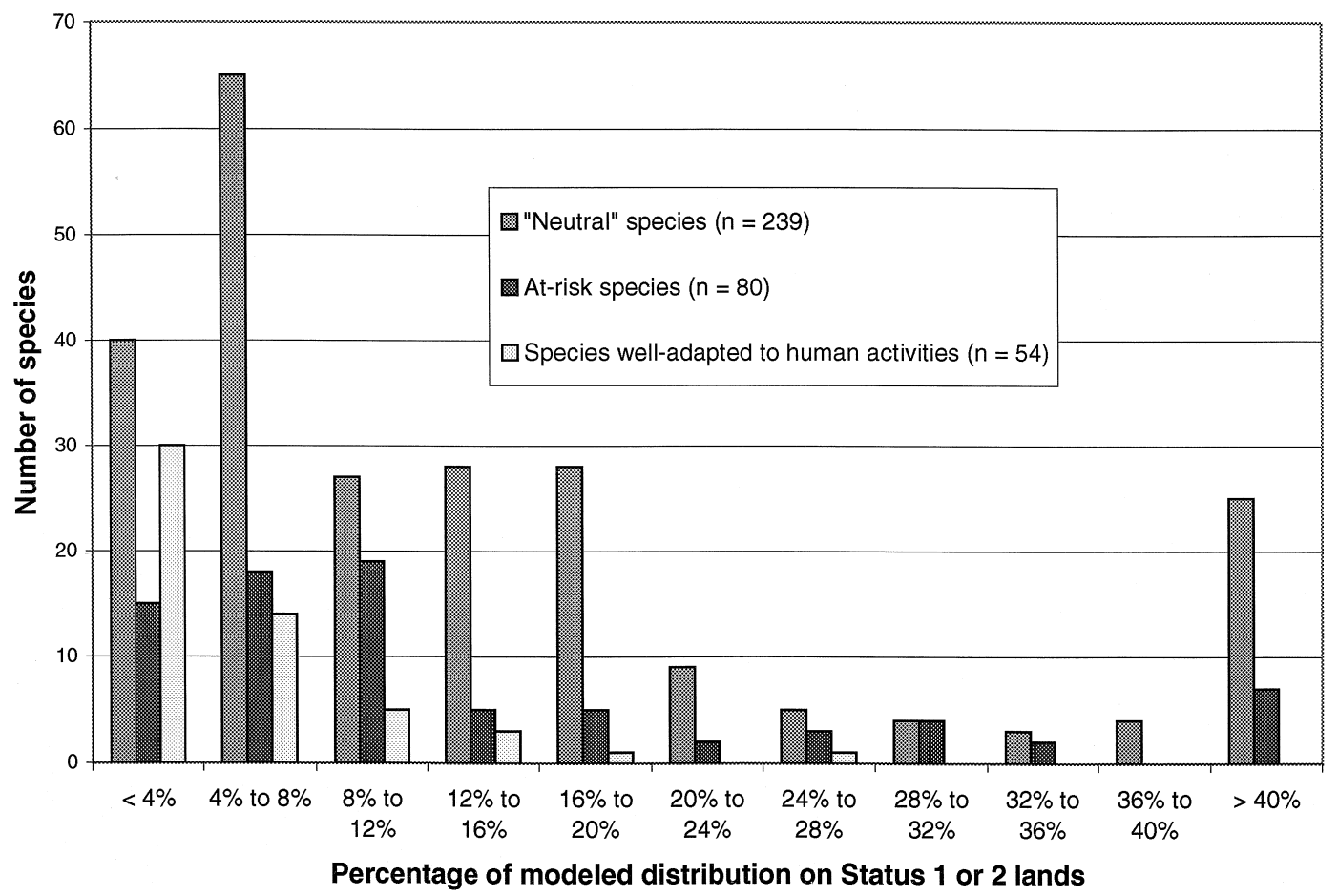

Fig. 5. Percent of modeled distribution on status 1 or 2 lands for at-risk species compared to other species.

tion) contains $42.5 \%$ (34 of 80$)$ at-risk species, $33 \%(18$ of 54) of well-adapted species, and 27\% (64 of 238) of neutral species.

Table 4 shows the percentage overlap of the top 80 species selected by four different prioritization methods: our subjective list of at-risk species, lowest percentage representation on status 1 or 2 lands, lowest absolute representation on status 1 or 2 lands, and smallest total area of modeled distribution. A random overlap is $29 \%$, since 80 species represent $29 \%$ of the total 373 species included in the analysis. The overlap between at-risk species and species with the lowest percentage representation is $18 \%$, which is lower than expected if species were randomly selected. The overlap between at-risk species and species with either a low absolute representation on status 1 or 2 lands or a small modeled area was similar (34 and 33\%, respectively), but not much higher than a random overlap. The highest overlap between prioritization methods $(81 \%)$ is between species with a low absolute representation on status 1 and 2 lands and species with a small modeled distribution.

\section{Discussion}

Caicco et al. (1995) prioritized vegetation communities in Idaho by ranking them in inverse order of total area represented on status 1 or 2 lands. Stoms et al. (1998) prioritized vegetation communities in the Great Basin by their current percentage representation on status 1 or 2 lands, combined with a qualitative estimate of their vulnerability to expected future land use activities. Merrill et al. (1996) based prioritization in Wyoming on percentage representation in combination with total area representation and qualitative estimates of vulnerability to expected future land use and current land management practices. For vertebrates, Kiester et al. (1996) prioritized species in Idaho

Table 4

Percentage overlap between the 80 highest priority species based on various selection criteria

\begin{tabular}{|c|c|c|c|c|}
\hline & At-risk & $\begin{array}{l}\text { Lowest } \% \text { on } \\
\text { status } 1,2\end{array}$ & $\begin{array}{l}\text { Lowest area on } \\
\text { status } 1,2\end{array}$ & $\begin{array}{l}\text { Lowest total } \\
\text { modeled area }\end{array}$ \\
\hline At-risk & - & 18 & 34 & 33 \\
\hline Lowest $\%$ on status 1,2 & & - & 40 & 23 \\
\hline Lowest area on status 1,2 & & & - & 81 \\
\hline Lowest total modeled area & & & & - \\
\hline
\end{tabular}


based principally on the total modeled area on status 1 or 2 lands. Merrill et al. (1996) based prioritization of vertebrates on their percentage representation on status 1 or 2 lands in combination with total area protected and incorporation of subjective evaluation of the results.

The 7 cover types we identified as having the highest conservation priority based on anthropogenic conversion (Sections 3.2 and 3.3), vary greatly in the percentage of their extant distribution on status 1 and 2 lands: 2 have less than $5 \%$ representation, 2 have between 5 and $10 \%$ representation, and 3 (the late-seral forest types) have greater than $10 \%$ representation. One of the problems with assessing conservation priorities using percentage representation of current distributions on protected lands is that communities or species most sensitive to human activities often suffer disproportionate reduction outside of these areas. Thus, their current distributions are often disproportionately wellrepresented on protected lands, while vegetation communities that increase as a result of human activities and species well-adapted to those communities will be disproportionately represented on unprotected lands. In Washington State, the protection status of west-side forests of different seral stage illustrates this effect: Early- and mid-seral forests of the Puget-Willamette trough, Sitka spruce, and western hemlock zones all have less than $2 \%$ (and usually less than $1 \%$ ) representation on status 1 and 2 lands, while extant late-seral conifer forest in these zones have a disproportionately high percentage representation: $12.6 \%$ for late-seral Pseudotsuga menziesii/Tsuga heterophylla forest in the Puget-Willamette trough zone, $46.0 \%$ for late-seral Picea sitchensis/Tsuga heterophylla forest in the Sitka spruce zone, and $37.3 \%$ for late-seral Tsuga heterophylla/Pseudotsuga menziesii/Thuja plicata forest in the western hemlock zone. Percentage representation of early-and mid-seral forests is low and of late-seral forests is high because forests outside of status 1 and 2 lands are more likely to be logged, so an increasing percentage of late-seral forests will occur on status 1 or 2 lands, although the absolute amount of such forests may continue to decline. Upland steppe communities are another example of the same phenomena, except that unprotected communities are more likely to be converted to agriculture by human activities than to have their seral stage altered. Currently, $2 \%$ of the extant mesic steppe is on status 1 and 2 lands, however, virtually all the agricultural land in the zone was originally upland steppe. Thus, only $0.8 \%$ of the original mesic steppe is on status 1 or 2 lands. As upland steppe outside protected areas continues to be converted to agriculture or development, the percentage of remaining steppe on status 1 or 2 lands will continue to increase.

Vertebrate species show a similar phenomenon. Native species well-adapted to human activities gen- erally have a lower percentage representation on status 1 or 2 lands than other species (Fig. 5). At-risk species have a percentage representation on status 1 or 2 lands similar to species overall, despite many of the species in the at-risk group being selected because their ranges were restricted to lower elevations where there are fewer protected areas. In general, while a low percentage representation on protected lands could be considered a factor is assessing conservation priority, the assumption that a low percentage representation on protected lands indicates a species is vulnerable to human activities is invalid. In Washington, if conservation priorities are based on percentage representation on status 1 and 2 lands, species well-adapted to human activities will be disproportionately represented among species selected as high conservation priorities (Table 4). Merrill et al. (1996, p. 81) likewise noted that "using the proportion of the land base or habitat in status 1 and 2 lands as a criterion to evaluate species protection may have overemphasized the need for protection of some common or wide-spread land cover types...or vertebrate species....and under-represented some species that had a restricted distribution and only a small amount (but large proportion) that was protected".

Alternately, conservation priorities may be determined by ranking communities by their absolute representation on protected lands. A problem with the absolute representation approach is that communities and species, even in the absence of human impact, vary widely in the amount of area they cover, which affects their absolute representation on protected lands. For example, wetlands in most landscapes occupy less area than upland communities, and higher elevation communities tend to occupy less area than lower elevation communities. Caicco et al. (1995) identified conservation priorities in Idaho as vegetation types with less than 10,000 ha representation on status 1 or 2 lands. Idaho (21 million ha) is comparable in size to Washington (17.5 million ha). Three of the 7 cover types we identified as highest priorities based on anthropogenic conversion and historic extant would be priorities based on Caicco et al.'s (1995) criterion: late-seral forests in the Puget-Willamette trough zone $(2,500$ ha representation), wetlands in the Puget-Willamette trough zone (4,300 ha); and west-side woodland/prairie mosaic in the Puget-Willamette trough zone (2,600 ha). An additional 2 of the 7 would be close to the 10,000 ha criterion: late-seral forests in the Sitka spruce $(14,700$ ha representation) and upland mesic steppe (13,700 ha representation). The remaining 2 of the 7 have far more than the 10,000 ha representation: late-seral forest in the western hemlock zone $(110,300$ ha representation) and upland arid steppe (164,000 ha). Furthermore, while an absolute representation criterion would prioritize many Washington communities that truly are vulnerable, the absolute representation criterion places the conservation 
emphasis on communities of limited extent, such as wetlands and hardwood forest patches in conifer-dominated areas (Table 2). While many of these small communities should have more protection (notably wetlands), others are not particularly vulnerable to human activity. Using an absolute representation criteria, eastside Populus tremuloides/Populus trichocarpa stands, which have historically covered a relatively small area, would be a higher priority than e.g. late-seral forest in the Puget-Willamette trough zone, which has been nearly eliminated. Absolute representation is also affected by the relative resolution to which communities are defined. Subdividing steppe communities finer than "mesic" and "arid" steppe or subdividing forest communities by understory as well as overstory would create more classes of smaller size.

There are analogous difficulties when attempting to assess conservation priorities of individual species based on their absolute representation on protected lands. Using absolute representation on status 1 or 2 lands selects more at-risk species than using percentage representation on status 1 or 2 lands (Fig. 6; Table 4), but still prioritizes numerous species well-adapted to human activities. The principal criterion for adequate representation for Kiester et al.'s (1996) prioritization of vertebrate species in Idaho was that the species be modeled on three or more areas of at least 10,000 ha within status 1 or 2 lands. [Their criterion was based on Schonewald-Cox's (1983) criterion for medium-sized mammals.] If we were to assume that species with more than 30,000 ha representation on status 1 or 2 lands in
Washington are adequately protected, then 38\% (30 of 80) of at-risk species, $21 \%$ (49 of 238) of neutral species, and $22 \%$ (12 of 54 ) of species well-adapted to human activities would require greater protection. Thus, while absolute representation would prioritize proportionately more at-risk species than other species, it would also prioritize many species well-adapted to human activities, and most at-risk species would be considered adequately protected. Among the at-risk species that would be considered adequately protected are the spotted owl (Strix occidentalis — a Federally endangered species), which has 878,900 ha $(33.1 \%)$ of its modeled distribution on status 1 or 2 lands in Washington and the marbled murrelet (Brachyramphus marmoratus - a Federally threatened species), which has 280,000 ha $(25.0 \%)$ representation. Among the species well-adapted to people that would require greater protection under the 30,000 ha criterion is Anna's hummingbird (Calypte anna), which has 500 ha $(<1 \%)$ of its modeled distribution on status 1 or 2 lands. Anna's hummingbird, a species formerly rare in Washington, has become common in many residential areas where it relies on feeders and introduced flowers (Cassidy et al., 1997, Vol. 4). Like Anna's hummingbird, many of the species well-adapted to human activities do poorly on existing status 1 and 2 lands.

Our data for Washington indicate that absolute representation on status 1 or 2 lands is more of a reflection of the total area occupied by a species than it is of the species' risk status, i.e. the less area a species occurs on, generally the lower the absolute representation on status 1 or 2

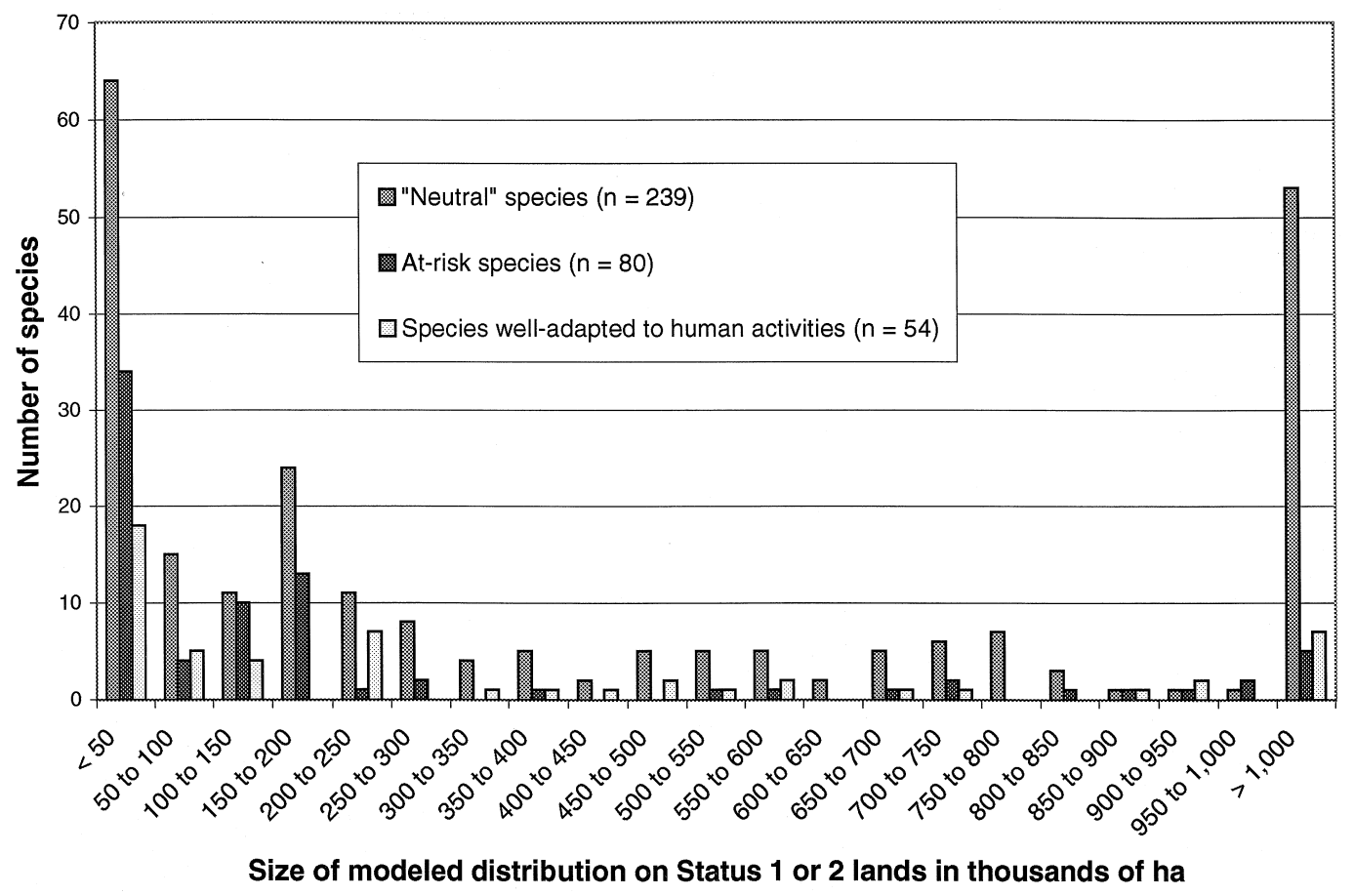

Fig. 6. Size of modeled distributions on status 1 or 2 lands for at-risk species compared to other species. 
lands. Prioritizing species based on absolute representation on status 1 or 2 lands gives results similar to prioritizing species based simply on total modeled area for a species (Table 4). The degree of overlap between at-risk species, and the 80 highest priority species using either absolute representation on status 1 or 2 lands or total modeled area, was similar. Our results suggest that prioritization based on absolute representation on status 1 or 2 lands is not much different than basing prioritization on total area occupied by a species.

We conclude that, in general, in Washington, conservation prioritization based on current protection status gives different results than prioritization based on more traditional methods. The rationale for basing prioritization ranking by protection status alone is to “...preserve biological diversity before it becomes rare, and...to consider all native species throughout an entire region." (Kiester et al., 1996, p. 1333). The ultimate goal is to allocate scarce conservation resources to achieve the greatest benefits for the most species (Scott et al., 1993; Caicco et al., 1995; Kiester et al., 1996). The danger of this approach is that scarce conservation resources may be shifted away from species most likely to need them at the present time and towards species unlikely to require protection in the foreseeable future. Of course, the future is unpredictable, and species thriving today may have a change in fortunes tomorrow.

Another danger of using current protection status is that a prioritization technique that produces counterintuitive results is unlikely to engender confidence in the process. For example, in Washington State, the issue of logging "old-growth" rain forests of the Pacific Northwest (i.e. late-seral forests in the Sitka spruce and western hemlock zones), and the consequential decline of late-seral forest-dependents, notably the spotted owl and marbled murrelet, have been the focus of intense environmental controversy (USDA-USDI, 1994). The high conservation priority of old-growth rain forest is apparent when anthropogenic conversion is added as a component of the analysis, but neither old growth rain forests, spotted owls, nor marbled murrelets would be high conservation priorities based solely on representation on status 1 or 2 lands. Any prioritization method that failed to rank these communities and species as high priorities in Washington State is likely to be considered suspect by conservationists.

Stoms et al. (1998) and Merrill et al. (1996) added an evaluation of vulnerability to future human activity to their evaluations of vegetation priorities based on cur- rent protection status. In Washington State, this technique would have partly compensated for the deficiencies of using absolute or percentage representation and it has the advantage of not being reliant on knowledge (or lack of knowledge) of historic conditions. Late-seral forest, for example, has high economic value and the rate of permissible logging in such forests is an ongoing controversy. Remnant steppe communities, especially outside of protected lands, are vulnerable to grazing and invasion by exotics. Without knowing potential vegetation and historic conditions, however, it would be difficult to assess the possibilities for restoration or recovery.

The reactive conservation approach of allocating most resources to listed species is undesirable and costly, but a proactive approach that considers all native species or communities as equal also has serious drawbacks. In particular, assigning conservation priorities solely, or even primarily, on the basis of current protection status may shift scarce conservation resources away from species and communities that could most benefit from them.

\section{Acknowledgements}

Major support for the Washington State Gap Analysis Project, from which this paper was derived, was provided by the US Department of the Interior (US Fish and Wildlife Service, National Biological Survey, National Biological Service, US Geological SurveyBiological Resources Division [USGS-BRD]) to the University of Washington through the Washington Cooperative Fish and Wildlife Research Unit. C. E. Grue is an employee of the USGS-BRD. The Unit is supported by the USGS-BRD, University of Washington, and Washington Departments of Ecology, Fish and Wildlife, and Natural Resources. Additional support, financial and in-kind, was provided by the Washington Department of Fish and Wildlife, the Washington Department of Natural Resources, the University of Washington, Washington State University, the U.S. Forest Service, the Yakama Indian Nation, the Makah Indian Nation, the Seattle Audubon Society, The Nature Conservancy, and the many individual volunteers who collected species and land cover data. The comments of two anonymous reviewers and R. Gerald Wright greatly improved the manuscript. 
Appendix A. Species in Washington State considered most at-risk due to human activities

\begin{tabular}{|c|c|c|c|c|}
\hline Common name & Scientific name & $\begin{array}{l}\text { Total modeled } \\
\text { area }\end{array}$ & $\begin{array}{l}\% \text { on status } \\
1 \text { or } 2 \text { lands }\end{array}$ & $\begin{array}{l}\text { Area on status } \\
1 \text { or } 2 \text { lands }\end{array}$ \\
\hline Cope's giant salamander & Dicamptodon copei & $1,306,664$ & 17 & 217,902 \\
\hline Cascades torrent salamander & Rhyacotriton cascadae & 572,057 & 2 & 9313 \\
\hline Columbia torrent salamander & Rhyacotriton kezeri & 151,358 & 1 & 784 \\
\hline Olympic torrent salamander & Rhyacotriton olympicus & 395,721 & 46 & 182,601 \\
\hline Dunn's salamander & Plethodon dunni & 374,043 & 0 & 747 \\
\hline Larch mountain salamander & Plethodon larselli & 417,225 & 8 & 34,765 \\
\hline Van Dyke's salamander & Plethodon vandykei & 720,406 & 23 & 168,707 \\
\hline Tailed frog & Ascaphus truei & $2,804,866$ & 29 & 813,671 \\
\hline Cascades frog & Rana cascadae & $1,200,541$ & 48 & 579,452 \\
\hline Columbia spotted frog & Rana luteiventris & $4,188,980$ & 10 & 399,849 \\
\hline Oregon spotted frog & Rana pretiosa & 8942 & 18 & 1575 \\
\hline Northern leopard frog & Rana pipiens & 30,693 & 7 & 2109 \\
\hline Western pond turtle & Clemmys marmorata & 20,074 & 0 & 51 \\
\hline Short-horned lizard & Phrynosoma douglassii & $2,520,659$ & 7 & 177,886 \\
\hline Sagebrush lizard & Sceloporus graciosus & $1,597,520$ & 10 & 161,272 \\
\hline Side-blotched lizard & Uta stansburiana & $1,276,458$ & 12 & 151,560 \\
\hline Night snake & Hypsiglena torquata & $2,502,680$ & 7 & 184,092 \\
\hline California mountain kingsnake & Lampropeltis zonata & 6393 & 2 & 128 \\
\hline Striped whipsnake & Masticophis taeniatus & $1,260,407$ & 12 & 145,432 \\
\hline Pygmy shrew & Sorex hoyi & 620,945 & 5 & 31,594 \\
\hline Merriam's shrew & Sorex merriami & 669,291 & 11 & 74,360 \\
\hline Keen's myotis & Myotis keenii & 582,631 & 20 & 117,062 \\
\hline Silver-haired bat & Lasionycteris noctivagans & $8,237,025$ & 16 & $1,285,213$ \\
\hline Townsend's big-eared bat & Plecotus townsendii & $14,701,414$ & 5 & 714,019 \\
\hline Black-tailed jack rabbit & Lepus californicus & $1,653,915$ & 10 & 158,786 \\
\hline White-tailed jack rabbit & Lepus townsendii & 878,147 & 2 & 14,471 \\
\hline Pygmy rabbit & Brachylagus idahoensis & 56,352 & 0 & 0 \\
\hline Townsend's ground squirrel & Spermophilus townsendii & 717,335 & 11 & 78,972 \\
\hline Washington ground squirrel & Spermophilus washingtoni & 576,812 & 4 & 22,358 \\
\hline Least chipmunk & Tamias minimus & $1,559,518$ & 8 & 129,532 \\
\hline Western gray squirrel & Sciurus griseus & 142,886 & 4 & 5835 \\
\hline Western pocket gopher & Thomomys mazama & 16,107 & 46 & 7462 \\
\hline Northern grasshopper mouse & Onychomys leucogaster & $1,609,029$ & 10 & 158,819 \\
\hline Sagebrush vole & Lemmiscus curtatus & $1,577,829$ & 7 & 108,292 \\
\hline Gray wolf & Canis lupus & $1,800,812$ & 53 & 951,997 \\
\hline Grizzly bear & Ursus arctos & $1,800,812$ & 53 & 951,997 \\
\hline Marten & Martes americana & $4,770,879$ & 25 & $1,171,448$ \\
\hline Fisher & Martes pennanti & $2,620,635$ & 19 & 506,565 \\
\hline Wolverine & Gulo gulo & $4,063,125$ & 31 & $1,273,430$ \\
\hline Badger & Taxidea taxus & $2,916,902$ & 6 & 175,232 \\
\hline Lynx & Lynx canadensis & 920,756 & 30 & 278,162 \\
\hline Caribou & Rangifer tarandus & 80,877 & 17 & 13,709 \\
\hline Bighorn sheep & Ovis canadensis & 643,305 & 15 & 99,507 \\
\hline Common loon & Gavia immer & 16,030 & 4 & 649 \\
\hline Clark's grebe & Aechmophorus clarkii & 29,385 & 9 & 2633 \\
\hline Western grebe & Aechmophorus occidentalis & 42,034 & 11 & 4671 \\
\hline American bittern & Botaurus lentiginosus & 103,383 & 7 & 6826 \\
\hline Canvasback & Aythya valisineria & 5637 & 10 & 566 \\
\hline Harlequin duck & Histrionicus histrionicus & $2,993,249$ & 34 & $1,019,582$ \\
\hline Cooper's hawk & Accipiter cooperii & $1,466,157$ & 3 & 42,259 \\
\hline Northern goshawk & Accipiter gentilis & $3,683,488$ & 30 & $1,118,511$ \\
\hline
\end{tabular}


Appendix A (continued)

\begin{tabular}{|c|c|c|c|c|}
\hline Common name & Scientific name & $\begin{array}{l}\text { Total modeled } \\
\text { area }\end{array}$ & $\begin{array}{l}\% \text { on status } \\
1 \text { or } 2 \text { lands }\end{array}$ & $\begin{array}{l}\text { Area on status } \\
1 \text { or } 2 \text { lands }\end{array}$ \\
\hline Ferruginous hawk & Buteo regalis & $1,034,611$ & 10 & 107,219 \\
\hline Peregrine falcon & Falco peregrinus & 633 & 68 & 430 \\
\hline Prairie falcon & Falco mexicanus & $1,620,420$ & 10 & 160,688 \\
\hline Sage grouse & Centrocercus urophasianus & 383,915 & 6 & 24,196 \\
\hline Sharp-tailed grouse & Tympanuchus phasianellus & 301,099 & 1 & 3163 \\
\hline Sandhill crane & Grus canadensis & 6104 & 26 & 1590 \\
\hline Snowy plover & Charadrius alexandrinus & 790 & 66 & 518 \\
\hline Long-billed curlew & Numenius americanus & $1,842,087$ & 8 & 141,309 \\
\hline Caspian tern & Sterna caspia & 95,813 & 11 & 10,974 \\
\hline Black tern & Chlidonias niger & 99,690 & 5 & 4525 \\
\hline Marbled murrelet & Brachyramphus marmoratus & $1,118,289$ & 25 & 280,100 \\
\hline Flammulated owl & Otus flammeolus & $1,247,218$ & 4 & 55,468 \\
\hline Burrowing owl & Speotyto cunicularia & $1,498,322$ & 7 & 109,338 \\
\hline Spotted owl & Strix occidentalis & $2,654,647$ & 33 & 878,873 \\
\hline Great gray owl & Strix nebulosa & 220,148 & 0 & 110 \\
\hline Short-eared owl & Asio flammeus & $5,221,402$ & 4 & 198,436 \\
\hline Lewis' woodpecker & Melanerpes lewis & 910,502 & 5 & 43,824 \\
\hline White-headed woodpecker & Picoides albolarvatus & 550,005 & 4 & 24,298 \\
\hline Pileated woodpecker & Dryocopus pileatus & $5,222,743$ & 17 & 902,213 \\
\hline Purple martin & Progne subis & 475,393 & 1 & 6085 \\
\hline Western bluebird & Sialia mexicana & $3,189,159$ & 3 & 107,250 \\
\hline Gray catbird & Dumetella carolinensis & 326,654 & 3 & 9125 \\
\hline Sage thrasher & Oreoscoptes montanus & $1,784,767$ & 9 & 164,392 \\
\hline Loggerhead shrike & Lanius ludovicianus & 930,472 & 12 & 114,742 \\
\hline Yellow warbler & Dendroica petechia & $8,060,920$ & 9 & 716,527 \\
\hline Yellow-breasted chat & Icteria virens & 886,895 & 5 & 43,635 \\
\hline Chipping sparrow & Spizella passerina & $4,292,445$ & 15 & 655,419 \\
\hline Brewer's sparrow & Spizella breweri & $2,048,671$ & 8 & 167,420 \\
\hline Sage sparrow & Amphispiza belli & 911,082 & 14 & 123,265 \\
\hline
\end{tabular}

\section{References}

Agee, J.K., Kertis, J., 1986. Vegetation Cover Types of the North Cascades. Report CPSU/UW 86-2, National Park Service Cooperative Park Studies Unit, College of Forest Resources, University of Washington, Seattle, Washington.

Annable, C.R., Peterson, P.M., 1988. Vascular Plants of the Kettle Range, Ferry County, Washington. Douglasia Occasional Papers, Washington Native Plant Society, University of Washington, Seattle. Vol. 3, pp. 62-96.

Arno, S.F., Hammerly, R.P., 1977. Northwest Trees, The Mountaineers, Seattle, WA.

Brockway, D.G., Topik, C., Hemstrom, M.A., Emmingham, W.H., 1983. Plant Association and Management Guide for the Pacific Silver Fr zone, Gifford Pinchot National Forest. R6-ECOL-130a1983, United States Department of Agriculture, Forest Service, Pacific Northwest Region.

Caicco, S.L., Scott, J.M., Butterfield, B., Csuti, B., 1995. A gap analysis of the management status of the vegetation of Idaho (USA). Conservation Biology 9, 498-511.

Call, W.A., 1974. Soil Survey of Cowlitz Area, Washington. United States Department of Agriculture, Soil Conservation Service.
Cassidy, K.M., Grue, C.E., Smith, M.R., Dvornich, K.M. (Eds.), 1997. Washington State Gap Analysis - Final Report. Washington Cooperative Fish and Wildlife Research Unit, University of Washington, Seattle, WA. Vol. 1-5.

Colville National Forest, 1978. Unpublished Map Titled: Colville National Forest 1974 Habitat Types. Cartographer uncertain; possibly L. Day.

Daubenmire, R., 1970. Steppe Vegetation of Washington. Originally Agriculture Experiment Station Publication XT0062. Reprinted in 1988 as EB1446, US Department of Agriculture and Home Economics, Washington State University, Pullman, WA.

Daubenmire, R., Daubenmire, J.B., 1968. Forest Vegetation of Eastern Washington and Northern Idaho. Technical Bulletin 60, Washington Agricultural Experiment Station, College of Agriculture, Washington State University, Pullman, WA.

del Moral, R., 1979. High-elevation vegetation of the Enchantment Lakes Basin, Washington. Canadian Journal of Botany 57, 1111-1130.

del Moral, R., Fleming, R.S., 1979. Structure of coniferous forest communities in western Washington: diversity and ecotope properties. Vegetatio 41, 143-154.

del Moral, R., Long, J.N., 1977. Classification of montane forest community types in the Cedar River drainage of western Washington, USA. Canadian Journal of Forest Resources 7, 217-225. 
Dobler, F.C., Eby, J., Perry, C., Richardson, S., VanderHaegen, M., 1996. Status of Washington's Shrub-steppe Ecosystem: Extent, Ownership, and Wildlife/Vegetation Relationships. Washington Department of Fish and Wildlife, Olympia, WA.

Douglas, G.W., Bliss, L.C., 1977. Alpine and high subalpine plant communities of the north Cascades Range, Washington and British Columbia. Ecological Monographs 47, 113-150.

Edwards Jr., T.C., Homer, C.H., Bassett, S.D., Falconer, A., Ramsey, R.D., Wight, D.W., 1995. Utah Gap Analysis: An Environmental Information System. Technical Report 95-1, Utah Cooperative Fish and Wildlife Research Unit, Utah State University, Logan, Utah.

Evans, R.L., Fibich, W.R., 1987. Soil Survey of Lewis County Area, Washington. United States Department of Agriculture, Soil Conservation Service.

Fonda, R.W., 1974. Forest succession in relation to river terrace development in Olympic National Park, Washington. Ecology 55, 927-942.

Fonda, R.W., Bliss, L.C., 1969. Forest vegetation of the montane and subalpine zones, Olympic Mountains, Washington. Ecological Monographs 39, 271-301.

Franklin, J.F., 1966. Vegetation and soils in the subalpine forests of the southern Washington Cascade Range. PhD dissertation, Washington State University, Pullman, Washington.

Franklin, J. F., Dyrness, C. T., 1973. Natural vegetation of Oregon and Washington. Reprinted 1988 by Oregon State University Press.

Franklin, J.F., Moir, W.H., Hemstrom, M.A., Greene, S.E., Smith, B.G., 1988. The forest communities of Mount Rainier National Park. Scientific Monograph Service No. 19, United States Department of the Interior, National Park Service, Washington, DC.

Gauthreaux, S.A., 1992. Preliminary list of migrants for Partners in Flight neotropical migratory bird conservation program. Partners in Flight Newsletter 2, 30 (winter 1992).

Hall, F.C., 1973. Plant Communities of the Blue Mountains in Eastern Oregon and Southeastern Washington. R6 Area Guide 3-1, United States Department of Agriculture, Forest Service, Pacific Northwest Region.

Harris, G.A., Chaney, M., 1984. Washington State Grazing Land Assessment. Printed by Washington State University Cooperative Extension for the Washington Rangeland Committee and Washington Conservation Commission.

Henderson, J.A., Lesher, R.D., Peter, D.H., Shaw, D.C., 1992. Field guide to the forested plant association of the Mt. Baker-Snoqualmie National Forest. R6-ECOL-TP-028-91, United States Department of Agriculture, Forest Service, Pacific Northwest Region.

Henderson, J.A., Peter, D.H., Lesher, R.D., Shaw, D.C., 1989. Forested Plant Association of the Olympic National Forest. R6ECOL-TP-001-88, United States Department of Agriculture, Forest Service, Pacific Northwest Region.

Johnson, G.J., Clausnitzer, R.R., 1992. Plant Associations of the Blue and Ochoco Mountains. R6-ERW-TP-036-92, United States Department of Agriculture, Forest Service, Pacific Northwest Region.

Kiester, R.A., Scott, J.M., Csuti, B., Noss, R.F., Butterfield, B., Sahr, K. et al., 1996. Conservation prioritization using GAP data. Conservation Biology 10, 1332-1342.

Kuramoto, R.T., Bliss, L.C., 1970. Ecology of subalpine meadows in the Olympic mountains, Washington. Ecological Monographs 40, 317-347.
Lang, F.A., 1961. A Study of Vegetation Change on the Gravelly Prairies of Pierce and Thurston Counties, Western Washington. MS thesis, University of Washington, Seattle, Washington.

Mack, R.N., 1986. Alien plant invasion into the Intermountain West: A case history. In: Mooney, H.A., Drake, J.A. (Eds.), Ecology of Biological Invasions of North America and Hawaii. Springer-Verlag, New York, pp. 191-213.

Merrill, E.H, Kohley, T.W., Herdendorf, M.E., Reiners, W.A., Driese, K.L., Marrs, R.W., et al., 1996. The Wyoming Gap Analysis Project Final Report. Wyoming Cooperative Fish and Wildlife Research Unit, University of Wyoming, Laramie, Wyoming.

Schonewald-Cox, C.M., 1983. Guidelines to management: a beginning attempt. In: Schonewald-Cox, C.M., Chambers, S.M., MacBryde, B., Thomas, W.L. (Eds.), Genetics and Conservation: A Reference for Managing Wild Animal and Plant Populations. Benjamin/ Cummings. Menlo Park, CA, pp. 414-445.

Scott, J.M., Davis, F., Csuti, B., Noss, R., Butterfield, B., Groves, C. et al., 1993. Gap analysis: a geographic approach to protection of biological diversity. Wildlife Monographs 123, 1-41.

Smith, M.R., 1994. Evaluating the Conservation of Avian Diversity in Eastern Washington: A Geographic Analysis of Upland Breeding Birds. MS thesis, University of Washington, Seattle, WA.

Spies, T.A., Franklin, J.F., 1988. Old growth and forest dynamics in the Douglas-fir region of western Oregon and Washington. Natural Areas Journal 8, 190-201.

Stoms, D.M., Davis, F.W., Driese, K.L., Cassidy, K.M., Murray, M.P., 1998. Gap analysis of the vegetation of the intermountain semi-desert ecoregion. The Great Basin Naturalist 58, 199-216.

Taylor, R.J., Boss, T.R., 1975. Biosystematics of Quercus garryana in relation to its distribution on the state of Washington. Northwest Science 49, 49-57.

Topik, C., 1989. Plant Association and Management Guide for the Grand Fir Zone, Gifford Pinchot National Forest. R6-ECOL-TP006-88, United States Department of Agriculture, Forest Service, Pacific Northwest Region.

Topik, C., Halverson, N.M., Brockway, D.G., 1986. Plant Association and Management Guide for the Western Hemlock Zone, Gifford Pinchot National Forest. R6-ECOL-230b-1986, United States Department of Agriculture, Forest Service, Pacific Northwest Region.

USDA-USDI, 1994. Management of Habitat for Late-successional and Old-growth Forest Species within the Range of the Northern Spotted Owl. Final Supplement Environmental Impact Statement. US Department of Agriculture and US Department of the Interior. Available from US Fish and Wildlife Service, 911 NE 11th Avenue, Portland, OR, 97232.

Vanbianchi, R., Wagstaff, S.J., 1988. A Floristic Survey of Big Beaver Valley. Douglasia Occasional Papers, Washington Native Plant Society, University of Washington, Seattle, Washington, Volume 3, $1-61$.

Williams, C.K., Lillybridge, T.R., 1983. Forested Plant Associations of the Okanogan National Forest. R6-ECOL-132b-1983, United States Department of Agriculture, Forest Service, Okanogan National Forest.

Williams, C.K., Lillybridge, T.R., Smith, B.G., 1990. Forested Plant Associations of the Colville National Forest. United States Department of Agriculture, Forest Service, Colville National Forest.

Zar, J.H., 1984. Biostatistical Analysis, Prentice-Hall Inc, New Jersey. 